Prepared in cooperation with the New Mexico Environment Department

\title{
Preliminary Geophysical Interpretations of Regional Subsurface Geology near the Questa Mine Tailing Facility and Guadalupe Mountain, Taos County, New Mexico
}

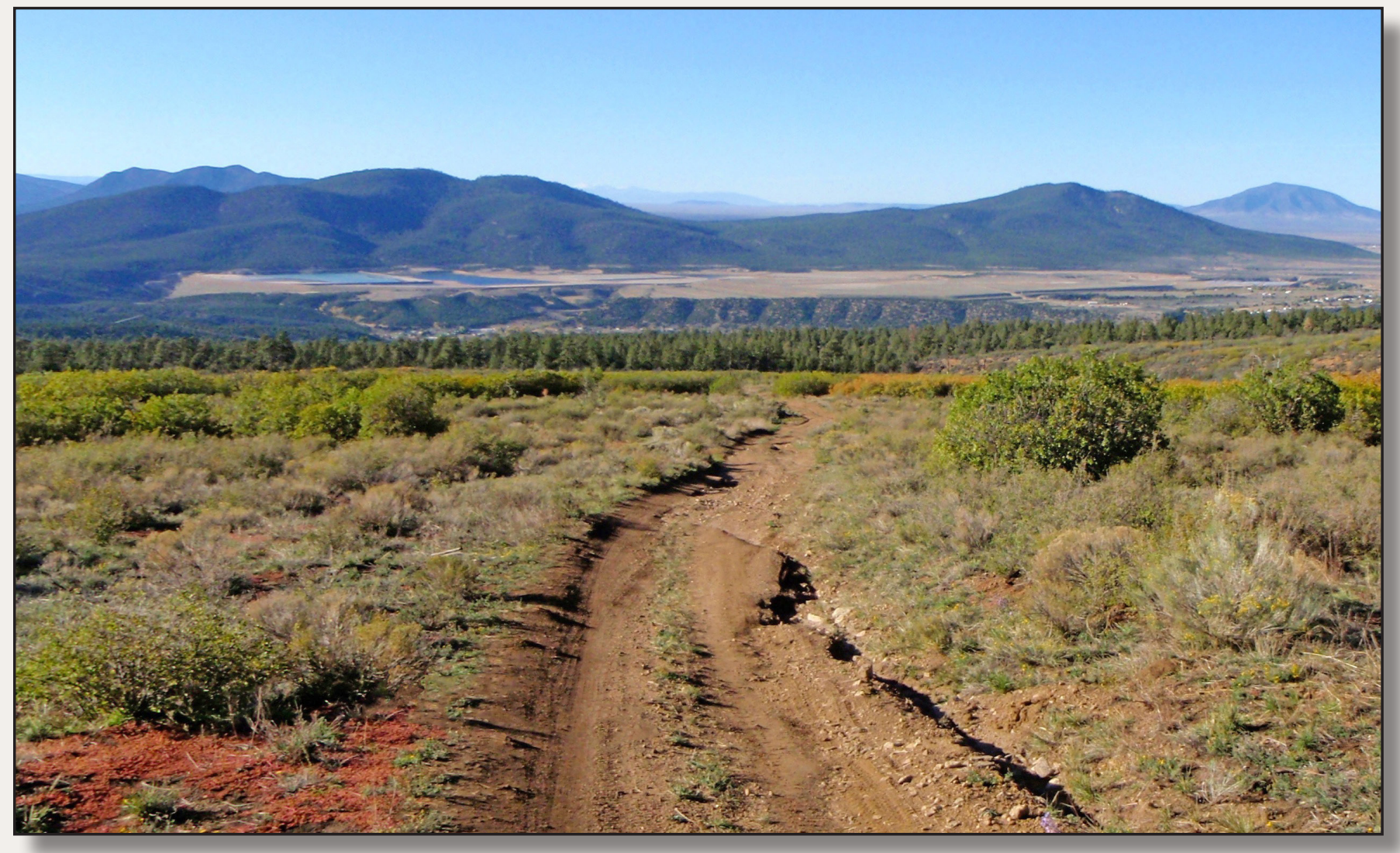

Open-File Report 2015-1129

U.S. Department of the Interior

U.S. Geological Survey 
Cover. Guadalupe Mountain and Questa Mine Tailing Facility. View to the northwest. Photograph by Paul Bauer. 


\section{Preliminary Geophysical Interpretations of Regional Subsurface Geology near the Questa Mine Tailing Facility and Guadalupe Mountain, Taos County, New Mexico}

By V.J.S. Grauch, Benjamin J. Drenth, Ren A. Thompson, and Paul W. Bauer

Prepared in cooperation with the New Mexico Environment Department

Open-File Report 2015-1129 


\title{
U.S. Department of the Interior SALLY JEWELL, Secretary
}

\section{U.S. Geological Survey Suzette M. Kimball, Acting Director}

\author{
U.S. Geological Survey, Reston, Virginia: 2015
}

For more information on the USGS - the Federal source for science about the Earth, its natural and living resources, natural hazards, and the environment—visit http://www.usgs.gov or call 1-888-ASK-USGS.

For an overview of USGS information products, including maps, imagery, and publications, visit http://www.usgs.gov/pubprod/.

Any use of trade, firm, or product names is for descriptive purposes only and does not imply endorsement by the U.S. Government.

Although this information product, for the most part, is in the public domain, it also may contain copyrighted materials as noted in the text. Permission to reproduce copyrighted items must be secured from the copyright owner.

Suggested citation:

Grauch, V.J.S., Drenth, B.J., Thompson, R.A., and Bauer, P.W., 2015, Preliminary geophysical interpretations of regional subsurface geology near the Questa Mine Tailing Facility and Guadalupe Mountain, Taos County, New Mexico: U.S. Geological Survey Open-File Report 2015-1129, 35 p., http://dx.doi.org/10.3133/ofr20151129.

ISSN 2331-1258 (online) 


\section{Acknowledgments}

This report was completed under a technical assistance agreement between the U.S. Geological Survey and the New Mexico Environment Department. However, the analysis and data acquisition of geophysical data were also funded by several other projects working in similar geographic areas. Additional funding sources included the Village of Questa, New Mexico Bureau of Geology and Mineral Resources, and National Cooperative Geologic Mapping Program (Federal and STATEMAP funds). 


\section{Contents}

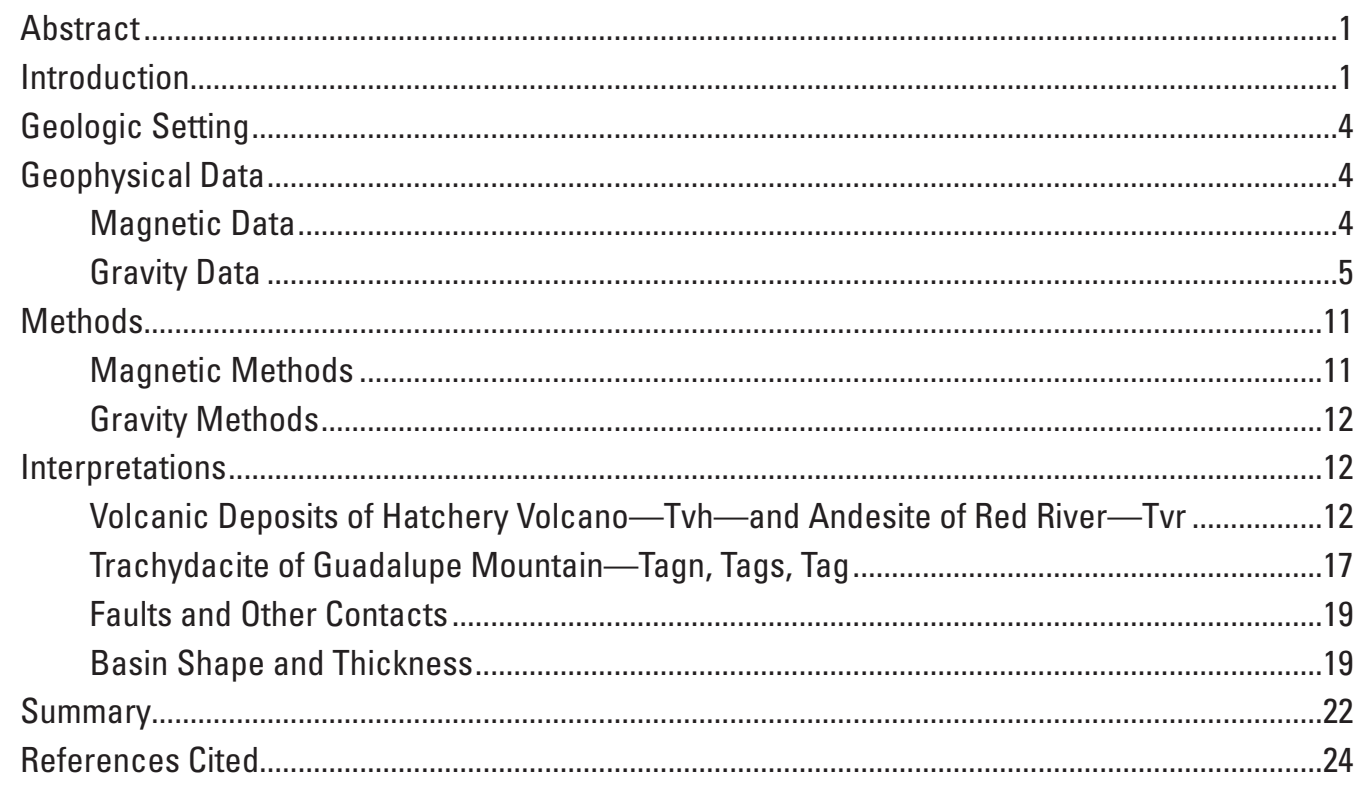

\section{Figures}

1. Map showing a satellite image of the study area from Google Earth, 2013......................2

2. Map of the regional geologic setting of the study area within the Rio Grande rift................3

3. Preliminary geologic map of the study area with unit descriptions................................6

4. Aeromagnetic map of the study area after application of the reduction-to-pole

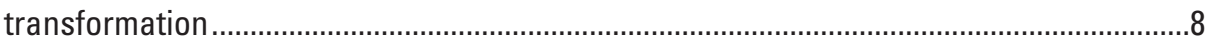

5. Data for four ground magnetic traverses acquired in 2014 ...........................................

6. Gravity map of the study area after removal of an isostatic regional field.......................10

7. Interpretations overlain on the aeromagnetic map with an explanation of

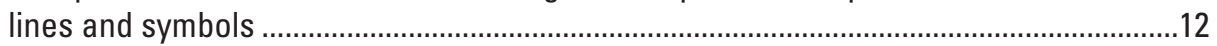

8. Map of a computed magnetic-terrain field for the study area........................................14

9. Geologic map of study area overlain by interpretative lines and annotations

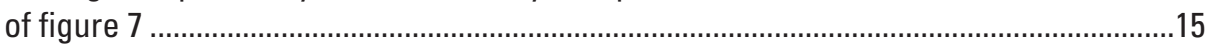

10. Map showing horizontal-gradient magnitude of the reduced-to-pole

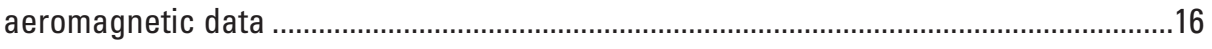

11. Gravity map overlain by interpretative lines and annotations of figure 7 ......................20

12. Alternative gravity models across the west-to-east profile $A-A^{\prime}$.................................21

13. Map showing interpretative lines and annotations overlain on the satellite image of the area 


\section{Conversion Factors}

Inch/Pound to International System of Units

\begin{tabular}{lcl}
\hline \multicolumn{1}{c}{ Multiply } & By & \multicolumn{1}{c}{ To obtain } \\
\hline foot $(\mathrm{ft})$ & Length & \\
mile $(\mathrm{mi})$ & 0.3048 & meter $(\mathrm{m})$ \\
\hline & 1.609 & kilometer $(\mathrm{km})$ \\
\hline pound per cubic foot $\left(\mathrm{lb} / \mathrm{ft}^{3}\right)$ & Density & \\
pound per cubic foot $\left(\mathrm{lb} / \mathrm{ft}^{3}\right)$ & 16.02 & kilogram per cubic meter $\left(\mathrm{kg} / \mathrm{m}^{3}\right)$ \\
\hline
\end{tabular}

\section{Datum}

Horizontal coordinate information is referenced to the North American Datum of 1983 (NAD 83).

\section{Abbreviations}

$\begin{array}{ll}\mathrm{A} / \mathrm{m} & \text { Amperes per meter } \\ \mathrm{Ma} & \text { Million years before present } \\ \mathrm{mgal} & \text { milligal } \\ \mathrm{nT} & \text { nanotesla } \\ \text { USGS } & \text { U.S. Geological Survey }\end{array}$




\title{
Preliminary Geophysical Interpretations of Regional Subsurface Geology near the Questa Mine Tailing Facility and Guadalupe Mountain, Taos County, New Mexico
}

\author{
By V.J.S. Grauch, ${ }^{1}$ Benjamin J.Drenth, ${ }^{1}$ Ren A. Thompson, ${ }^{1}$ and Paul W. Bauer ${ }^{2}$
}

\section{Abstract}

This report presents geophysical interpretations of regional subsurface geology in the vicinity of the Tailing Facility of the Questa Mine near Guadalupe Mountain, Taos County, New Mexico, in cooperation with the New Mexico Environment Department. The interpretations were developed from aeromagnetic data, regional gravity data, data from four ground magnetic traverses, geologic mapping, a digital elevation model, and information from a few shallow wells. The resolution of the geophysical data is only appropriate for a broad assessment of the regional setting. Aeromagnetic data provided the most comprehensive information for interpretation. Qualitative and semiquantitative interpretations indicate the nature and extent of volcanic rocks, their relative depths, and inferred contacts between them, as well as conjectured locations of faults. In particular, the aeromagnetic data indicate places where volcanic rocks extend at shallow depths under sedimentary cover. Trachydacites of Guadalupe Mountain are magnetic, but their associated aeromagnetic anomalies are opposite in sign over the northern versus the southern parts of the mountain. The difference indicates that lavas erupted during different magnetic-polarity events in the north (reverse polarity) versus the south (normal polarity) and therefore have different ages. We postulate a buried volcano with reverse-polarity magnetization lies under the northeast side of Guadalupe Mountain, which likely predated the exposed trachydacites. Faults interpreted for the study area generally align with known fault zones. We interpret a northern extension to one of these faults that crosses northwesterly underneath the Tailing Facility. Gravity data indicate that Guadalupe Mountain straddles the western margin of a subbasin of the Rio Grande rift and that significant ( $>400$ meters) thicknesses of both volcanic and sedimentary rocks underlie the mountain.

${ }^{1}$ U.S. Geological Survey

${ }^{2}$ New Mexico Bureau of Geology and Mineral Resources

\section{Introduction}

The Tailing Facility of the Questa Mine is located on the southeast side of Guadalupe Mountain, just west of Questa, New Mexico (fig. 1). As part of site remediation and reclamation, Chevron Mining, Inc., began a drilling program to expand existing information about groundwater at and near the Tailing Facility in 2014. Because groundwater and geology form the basis for reclamation designs and remedial systems at hard rock mine sites with acid and neutral mine drainage, the New Mexico Environment Department was interested in assessing the subsurface geology in the area before siting the wells. To accomplish the assessment of subsurface geology, the New Mexico Environment Department requested assistance from the U.S. Geological Survey (USGS) to do a brief evaluation and interpretation of existing geophysical data. At the time of the request, the USGS was conducting geophysical and geologic work for several other projects in the area in collaboration with New Mexico Bureau of Geology and Mineral Resources. The other projects, which represent different geographic areas that all overlap with parts of Guadalupe Mountain, include (1) a hydrogeology, geology, and geophysical study for the Village of Questa; (2) geologic mapping of the Guadalupe Mountain and Questa 7.5-minute quadrangles; (3) investigation of Cenozoic landscape evolution of the southern Rocky Mountains, and (4) geologic training of National Aeronautics and Space Agency (NASA) astronauts.

Available geophysical data for the study area are limited to regional gravity data, aeromagnetic data, and data from four ground magnetic traverses. The data only have adequate resolution for a broad assessment of the regional setting rather than mapping detailed subsurface geology, especially considering the known complexity and variability of the geology of the area. Thus, the scope of the study was restricted to qualitative and semiquantitative geophysical map interpretation to understand the regional setting of subsurface geology. This report presents interpretations of the gravity and magnetic maps for the study area, augmented by available 


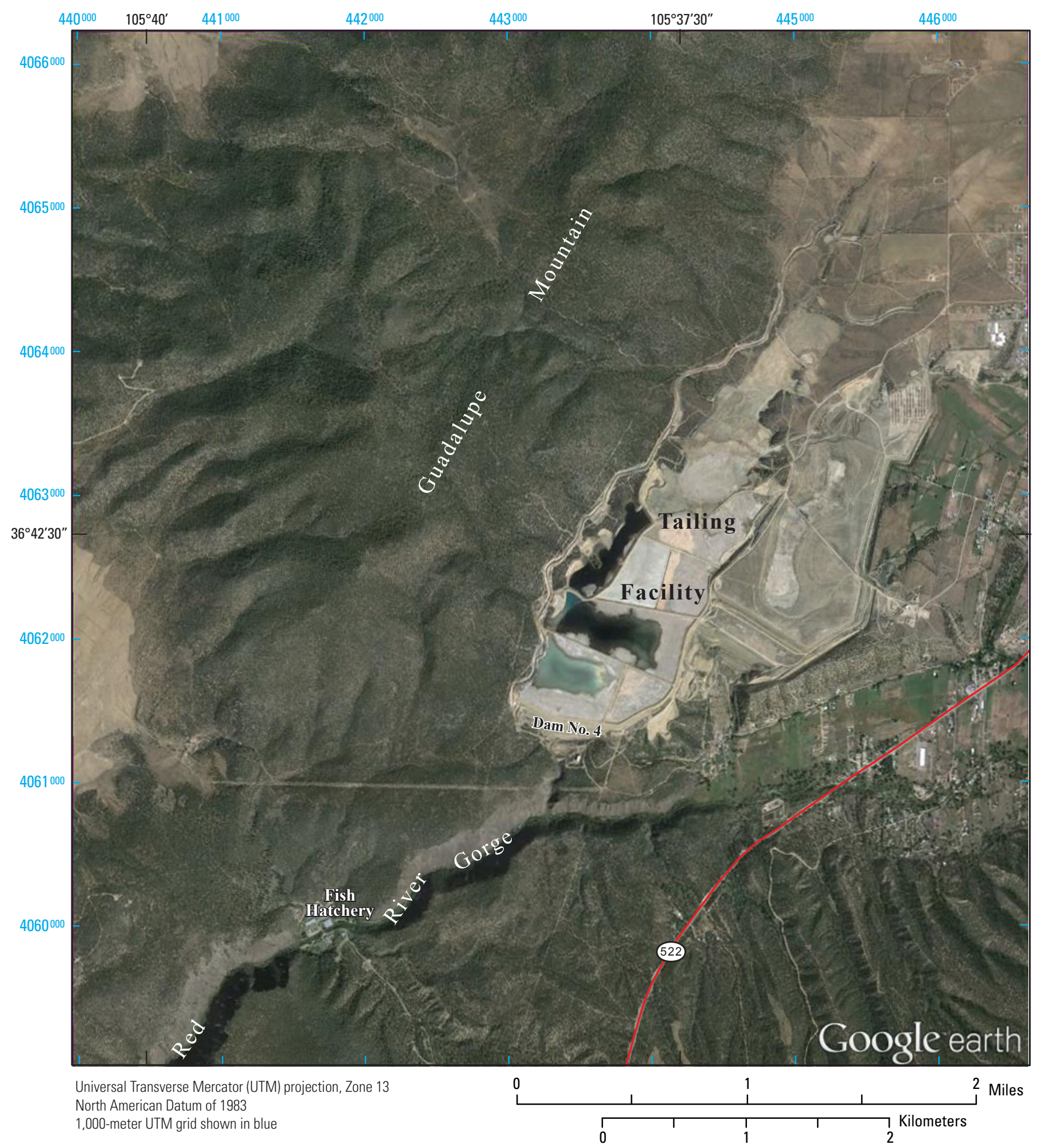

Figure 1. A satellite image of the study area from Google Earth, 2013. Tailing ponds and workings (Tailing Facility) related to the storage of waste from the Questa Mine are near the center of the image (lighter colored region). Study area location is on figure 2. The Village of Questa is just off the east side of the map along New Mexico Highway 522. 


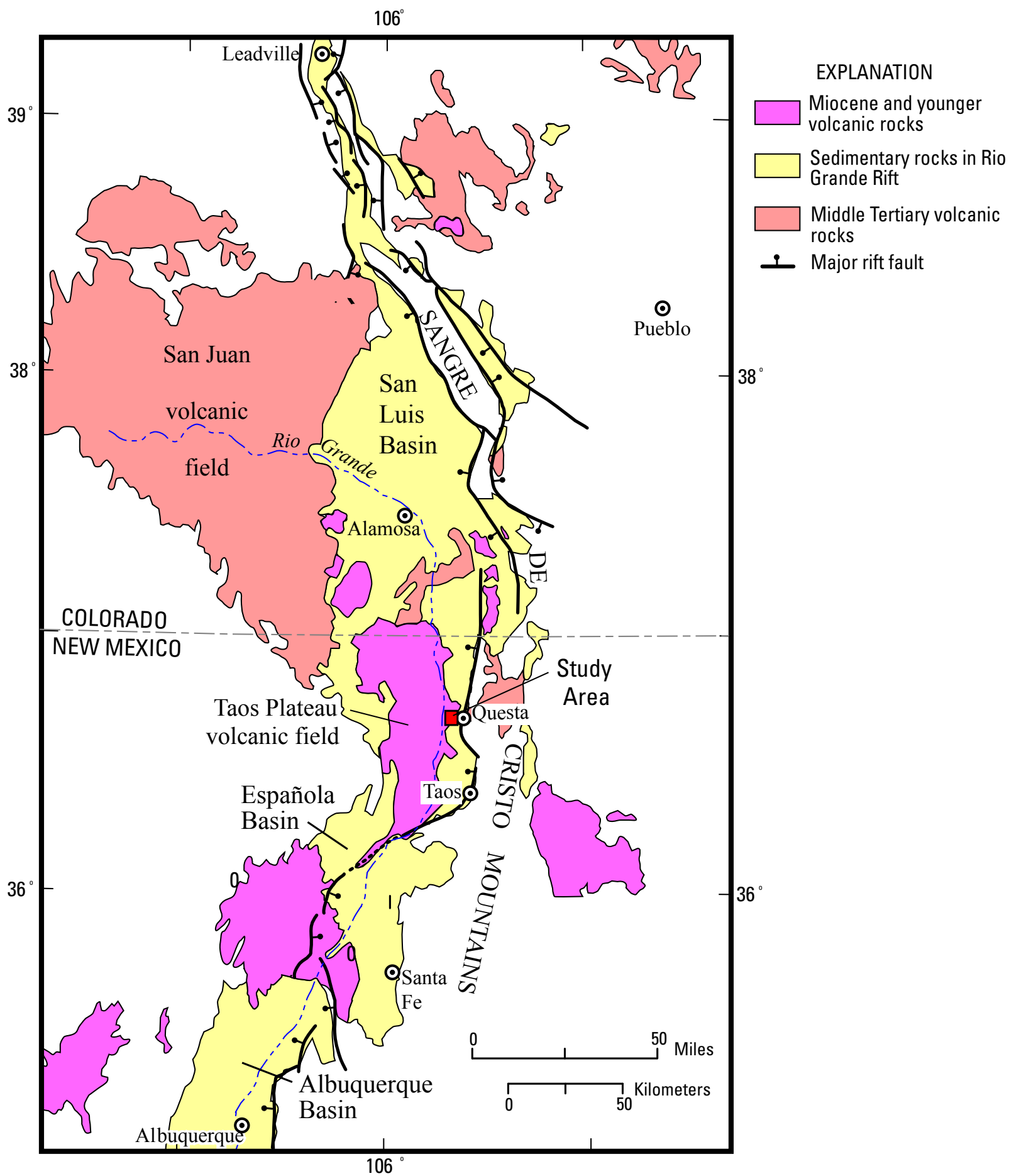

Figure 2. Regional geologic setting of the study area within the Rio Grande rift. Geology modified from Lipman (1983) and Keller and Baldridge (1999). 
geologic mapping and general information from a few water wells in the area provided by the New Mexico Environment Department. The geophysical interpretations are preliminary and somewhat subjective; they could be improved in the future with additional detailed ground-based geophysics, comprehensive physical-property studies, and deep drillholes. Readers should note also that the regional picture is an approximate representation of the subsurface geology. The results may not be accurate in representing details of what is encountered at a particular drill site.

\section{Geologic Setting}

The study area is located in the south-central part of the San Luis Basin at the eastern edge of the Taos Plateau volcanic field (fig. 2). The San Luis Basin is one of a series of northsouth elongated structural basins that compose the Cenozoic Rio Grande rift, which extends from Mexico to Colorado (Hudson and Grauch, 2013). As the basins developed in response to rifting of the crust, they filled with sediments and interbedded lava flows. These now poorly to moderately consolidated sediments, known as the Santa Fe Group, accumulated from 1 to 6 kilometers $(\mathrm{km})$ thick within the San Luis Basin mainly during the period 26-2 million years before present (Ma) (Ingersoll and others, 1990; Lipman, 1975; Lipman and Mehnert, 1979, Thompson and others, 1991; Bauer and Kelson, 2004). Pliocene lava flows of the Taos Plateau volcanic field erupted late in rift history (6-2 Ma) (fig. 2; Lipman and Mehnert, 1979; Dungan and others, 1984; Read and others, 2004). The volcanism was characterized by multiple eruptions of basaltic- and intermediate-composition magma from scattered cones and shield volcanoes. The total volume of eruptive material is predominantly olivine tholeiitic basalt (Lipman and Mehnert, 1979; Dungan and others, 1984; Read and others, 2004). Basin tilting and uplift of surrounding rift borders continued into Quaternary time, resulting in the accumulation of coalescing alluvial fans near the eastern mountain fronts and deep incision associated with the Rio Grande and Red River Gorges (Dungan and others, 1984; Heffern, 1990).

Figure 3 is a preliminary geologic map for the study area and brief description of units. The Quaternary surficial deposits represent many different types of young materials, including landslide, eolian, alluvial-fan, stream-channel, valley-floor, and stream-terrace deposits. Quaternary deposits - except for the youngest unit Qal—are represented as one undivided unit $(\mathrm{Qu})$ on figure 3 because they all have similar physical properties (low values of density and magnetization) for purposes of geophysical interpretation. The QuaternaryTertiary Lama Formation (QTl) is composed of alluvial-fan material of variable thickness that is widespread throughout the region. Maximum thickness is estimated from geologic mapping and well information to be 140 meters (m) near the mountain front east of Questa (P. Bauer, New Mexico Bureau of Geology and Mineral Resources, unpub. data, 2014).

Although Servilleta Basalt forms much of the landscape of the Taos Plateau volcanic field, only small portions are exposed in the study area. Lower and upper Servilleta Basalt (Tsbl and Tsbu) occur in the southwest and northwest corners of the study area, respectively.

Most of the study area is covered by trachydacites of north and south Guadalupe Mountain (Tagn and Tags, respectively) and volcanic deposits of Red River (Tvr) and Hatchery Volcano (Tvh). Limited exposures of Guadalupe Mountain trachydacite (Tag) in Red River Gorge are stratigraphically beneath, but not in contact with, north or south Guadalupe Mountain lavas. The exposures are tentatively associated with a subsurface unit inferred from the geophysical interpretation, discussed in the section of this report entitled "Interpretations." Tertiary Santa Fe Group sediments are not exposed in the study area but must be present in the subsurface based on drillhole information for the region (Winograd, 1959; New Mexico Office of State Engineer, unpub. well records, 2004-2015), and regional geophysical interpretations (Cordell and Keller, 1984; Keller and others, 1984; Grauch and Keller, 2004).

\section{Geophysical Data}

Magnetic and gravity data are measurements that show variations in the Earth's magnetic and gravity fields, respectively. The field variations, in turn, are produced by differences in the distribution and nature of the physical properties of rocks and sediments. Geophysicists use an understanding of the behavior of these fields combined with physical-property and geologic information to infer the nature of geology in the subsurface. For magnetic data, the applicable physical property is magnetization, which is determined by naturally occurring magnetic minerals in rocks and sediments. For gravity data, the applicable physical property is bulk density, which is the overall mass per unit volume of rocks, sediments, and their pore spaces.

\section{Magnetic Data}

Magnetic data, as considered in this report, are measurements of the Earth's magnetic field strength collected from a magnetometer mounted in an aircraft (aeromagnetic data) or mounted on a pole raised above the ground as the operator walks (ground magnetic data). Differences in total magnetization of rocks and sediments cause subtle variations in these data. Total magnetization is the vector sum of two components: remanent and induced. The induced component is a function of the quantity of magnetic minerals (commonly magnetite) and is a vector that is always oriented parallel to 
the present-day Earth's magnetic field. The remanent component represents the vector sum of all permanent magnetizations held by the magnetic minerals, which have fixed directions irrespective of applied magnetic fields (McElhinny, 1973; Blakely, 1995). Remanent components that are aligned with or opposite to the present-day Earth's field are considered to have normal or reverse polarity, respectively.

Total magnetizations of Tertiary volcanic rocks in the region of study are dominated by the remanent component and are typically orders of magnitude greater than those of sediments, which are dominated by the induced component (Reynolds and others, 1990; Grauch and Keller, 2004; M. Hudson, unpub. data, 2013). Moreover, comparisons of ages and polarities of several volcanoes suggest that the dominant remanent magnetizations of the volcanic rocks represent polarities acquired at the time of cooling (Grauch and Keller, 2004). Thus, volcanic rocks of different ages having reverse-polarity or normal-polarity remanent components can be distinguished on the basis of patterns of strongly negative versus strongly positive magnetic-field values, respectively. These patterns can be used to aid in mapping volcanic rocks of different ages.

The primary magnetic data used for this study come from a fixed-wing aeromagnetic survey described in Bankey and others (2005). Over the study area, data were mainly acquired along parallel east-west lines spaced $400 \mathrm{~m}$ apart, flown 200-300 m above ground. Several north-south lines were also flown $1,000 \mathrm{~m}$ apart. After flight-line data from the surveys were processed to remove Earth's field variations and reduce ordinary data-acquisition errors, they were interpolated onto a $50-\mathrm{m}$ grid. The gridded data were analytically continued from the variable observation surface to a surface draped $100 \mathrm{~m}$ above ground. A standard reduction-to-pole transformation was then applied to the gridded data using the local Earth's field declination of 10 degrees $\left(^{\circ}\right.$ ) and inclination of $64^{\circ}$. Reduction-to-pole transformations correct for shifts of anomalies away from the centers of their magnetic sources; these shifts are an effect of the oblique orientation of the measured magnetic field at high latitudes with respect to Earth's surface (Blakely, 1995). If not corrected, positive aeromagnetic anomalies for the study area would be offset to the southwest of their causative sources, and partial rings of negative anomalies would occur on the northeast.

Figure 4 is a color shaded-relief image of the final, reduced-to-pole aeromagnetic data. This image uses color to display the broad variations in the data and shading (analogous to illumination by the sun) to enhance many subtle details obliquely oriented to the direction of illumination.

In addition to aeromagnetic data, several ground magnetic traverses were acquired within the study area (white lines on fig. 4). These data were acquired from a magnetometer mounted on a pole held at head height as the operator traversed the ground on foot. The measurements of Earth's field strength were corrected for spikes and time breaks only and displayed in profile form on figure 5. Some interference from nearby metallic objects, such as barbed-wire fences and metal debris on the ground, as well as overhead low-voltage electrical transmission wires may have introduced some data problems, noted on the figure. The ground traverses are important for detecting relative depths to volcanic rocks within the top $25 \mathrm{~m}$ of the ground surface. As discussed in the section of the report entitled "Magnetic Methods," ground measurements can resolve the magnetic effects of much thinner, near-surface volcanic rocks than can be resolved from the air.

\section{Gravity Data}

Gravity data are particularly effective in determining the subsurface configuration of structural basins in the Rio Grande rift of New Mexico, owing to the generally large contrasts between low-density sedimentary fill and surrounding high-density crystalline bedrock (for example, Drenth and others, 2013; Grauch and Connell, 2013). Thus, large areas of measured gravity values that are lower than surrounding regions (gravity lows) can serve as proxies for understanding basin shape and volume of sediment. However, highdensity volcanic rocks that overlie or are interbedded with sediments in basins may substantially increase measured gravity values. This effect builds with increasing volume of volcanic rock but is difficult to predict without constrained geophysical modeling.

Gravity data for the study area were collected in 2009 and 2014 at locations (stations) shown in figure 6. The station locations were mapped using differential global positioning system (GPS) navigation. Field measurements were tied to a base station established at the post office in El Prado, New Mexico. Standard Bouguer corrections (Blakely, 1995) were applied for each gravity station using a reduction density of 2,670 kilograms per cubic meter $\left(\mathrm{kg} / \mathrm{m}^{3}\right)$. Terrain corrections were applied within a $167-\mathrm{km}$ radius to the data at each station using digital terrain data with a resolution as fine as $10 \mathrm{~m}$. The station data were then interpolated onto a grid at a 500-m interval. In order to focus on density variations within the upper crust, an isostatic regional field was removed from the terrain-corrected Bouguer gravity grid using parameters established for New Mexico by Heywood (1992). The resulting "isostatic residual gravity map" (fig. 6) generally isolates the gravity effects produced by sources within the upper $10 \mathrm{~km}$ of the crust (Simpson and others, 1986).

Reliability of the features depicted on the gravity map is highly dependent on station spacing, which is unevenly distributed across the study area (fig. 6). Spacing averages approximately $750 \mathrm{~m}$ for most of the area, providing only regional definition of the gravity field in the area. Larger gaps in coverage over the western side of Guadalupe Mountain span more than $2 \mathrm{~km}$. In these areas, the variations in the gravity values depicted by color contours on figure 6 are poorly constrained. 


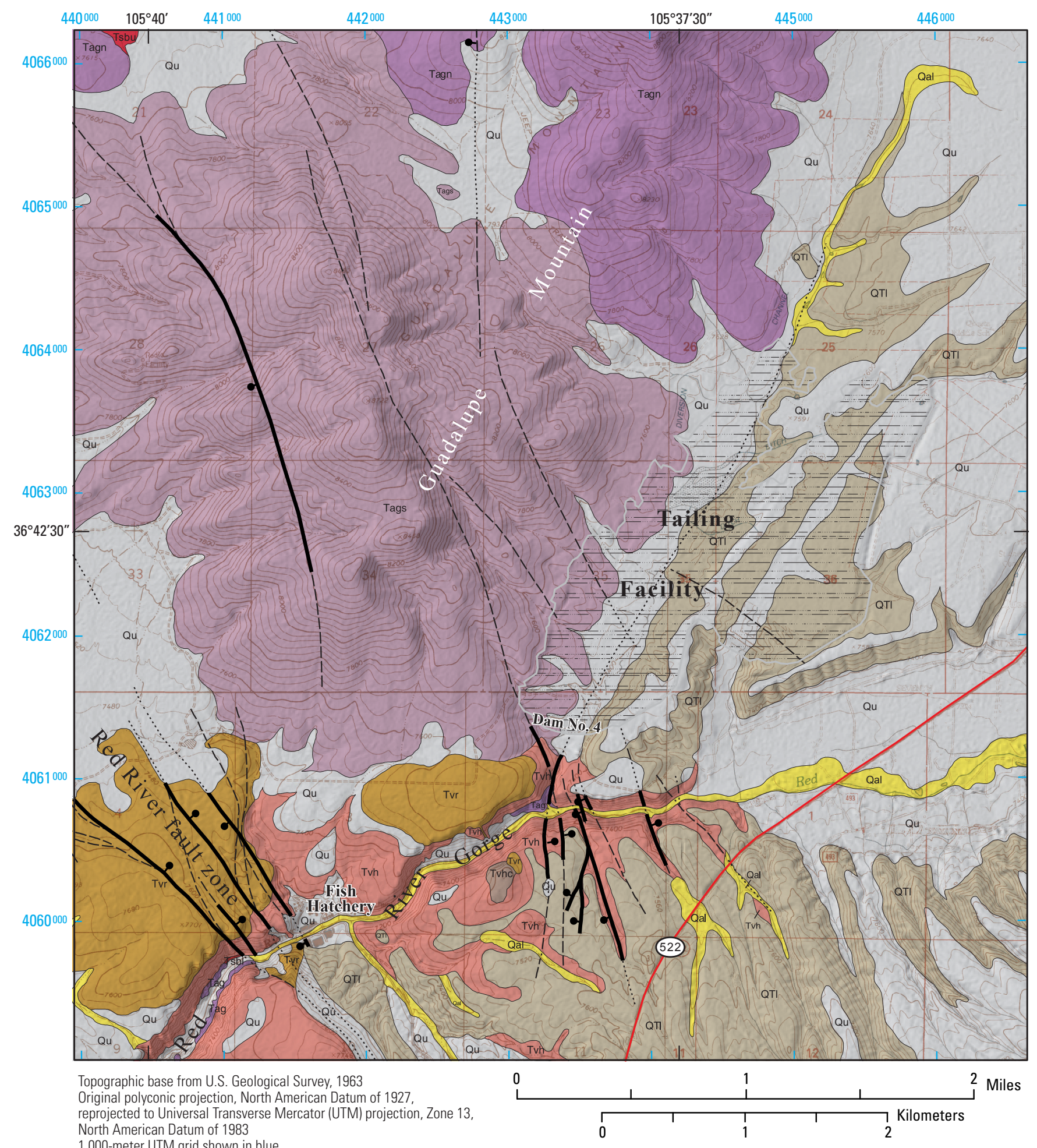

Figure 3. Preliminary geologic map of the study area with unit descriptions (modified from K. Kelson, U.S. Army Corps of Engineers, R. Thompson, U.S. Geological Survey, and P. Bauer, New Mexico Bureau of Geology and Mineral Resources, unpub. data, 2015.) 


\section{DESCRIPTION OF MAP UNITS}

Surficial Deposits

Qal Qal Alluvium (Holocene) - Poorly to moderately sorted sand, pebbles, and boulders in stream channels, valley floors, and active floodplains

$\mathrm{Qu} \quad \mathrm{Qu} \quad$ Undifferentiated alluvium, colluvium, and alluvial-fan and stream-terrace deposits (middle? Pleistocene to Holocene)_-Poorly sorted silt, sand, pebbles, and cobbles, and boulders

Older Sedimentary Deposits

QTI QT1 Lama Formation (Pliocene to middle Pleistocene)—Poorly sorted basin-fill deposits of the Santa Fe Group

Volcanic Deposits of the Taos Plateau Volcanic Field

Tsbu Tsbu Servilleta Basalt, upper (Pliocene)-Flows of dark-gray tholeiitic basalt, ${ }^{40} \mathrm{Ar} / 39 \mathrm{Ar}$ age of $3.78 \pm 0.08 \mathrm{Ma}$ (Cosca and others, 2014)

Tsbl Servilleta Basalt, lower (Pliocene) - Flows of dark-gray tholeiitic basalt, ${ }^{40} \mathrm{Ar} / 39 \mathrm{Ar}$ age of 5.22 $\pm 0.11 \mathrm{Ma}$ (Cosca and others, 2014)

Tvr Tvr Volcanic deposits of Red River volcano (Pliocene) — Dacite lava flow and near vent pyroclastic deposits, ${ }^{40} \mathrm{Ar} /{ }^{39} \mathrm{Ar}$ age determination of 4.67 $\pm 0.06 \mathrm{Ma}$ (Thompson and others, 2011)

Tvhc Tvhe Volcanic deposits of Hatchery volcano, near vent (Pliocene)-Near-vent deposits associated with lava flows of map unit Tvh, predominantly cinder, spatter and agglutinate, isolated exposures on south side of Red River gorge

Tvh Tvh Volcanic deposits of Hatchery volcano (Pliocene)_-Includes a sequence of dominantly andesitic lava flow, intercalated volcanic breccia, and locally, near vent pyroclastic deposits, ${ }^{40} \mathrm{Ar} /{ }^{39} \mathrm{Ar}$ age determination of 4.82 $\pm 0.07 \mathrm{Ma}$ (Thompson and others, 2011)

Tagn Tagn Trachydacite of Guadalupe Mountain, north (Pliocene)_Predominantly trachydacite lava flows and associated near-vent pyroclastic deposits; a ${ }^{40} \mathrm{Ar} / 39 \mathrm{Ar}$ age of 5.04 $\pm 0.04 \mathrm{Ma}$ was obtained from a lava flow at the north end of Guadalupe Mountain (Thompson and others, 2011)

Tags Tags Trachydacite of Guadalupe Mountain, south (Pliocene)—Predominantly trachydacite lava flows and associated near-vent pyroclastic deposits, Appelt (1998) reported ${ }^{40} \mathrm{Ar} /{ }^{39} \mathrm{Ar}$ ages of $5.11 \pm 0.08$ and $5.34 \pm 0.06$ Ma for groundmass separates from the south side of Guadalupe Mountain; a similar ${ }^{40} \mathrm{Ar} / 39 \mathrm{Ar}$ age $(5.27 \pm 0.05)$ was obtained from the base of the volcanic section in the Red River gorge (Cosca and others, 2012)

Tag Tag Trachydacite of Guadalupe Mountain, undifferentiated (Pliocene)—Predominantly trachydacite lava flows exposed at the base of volcanic section in Red River gorge

Disturbed ground

Normal fault, dashed where inferred, dotted where concealed; ball on downthrown side

Figure 3. Preliminary geologic map of the study area with unit descriptions (modified from K. Kelson, U.S. Army Corps of Engineers, R. Thompson, U.S. Geological Survey, and P. Bauer, New Mexico Bureau of Geology and Mineral Resources, unpub. data, 2015.)—Continued 


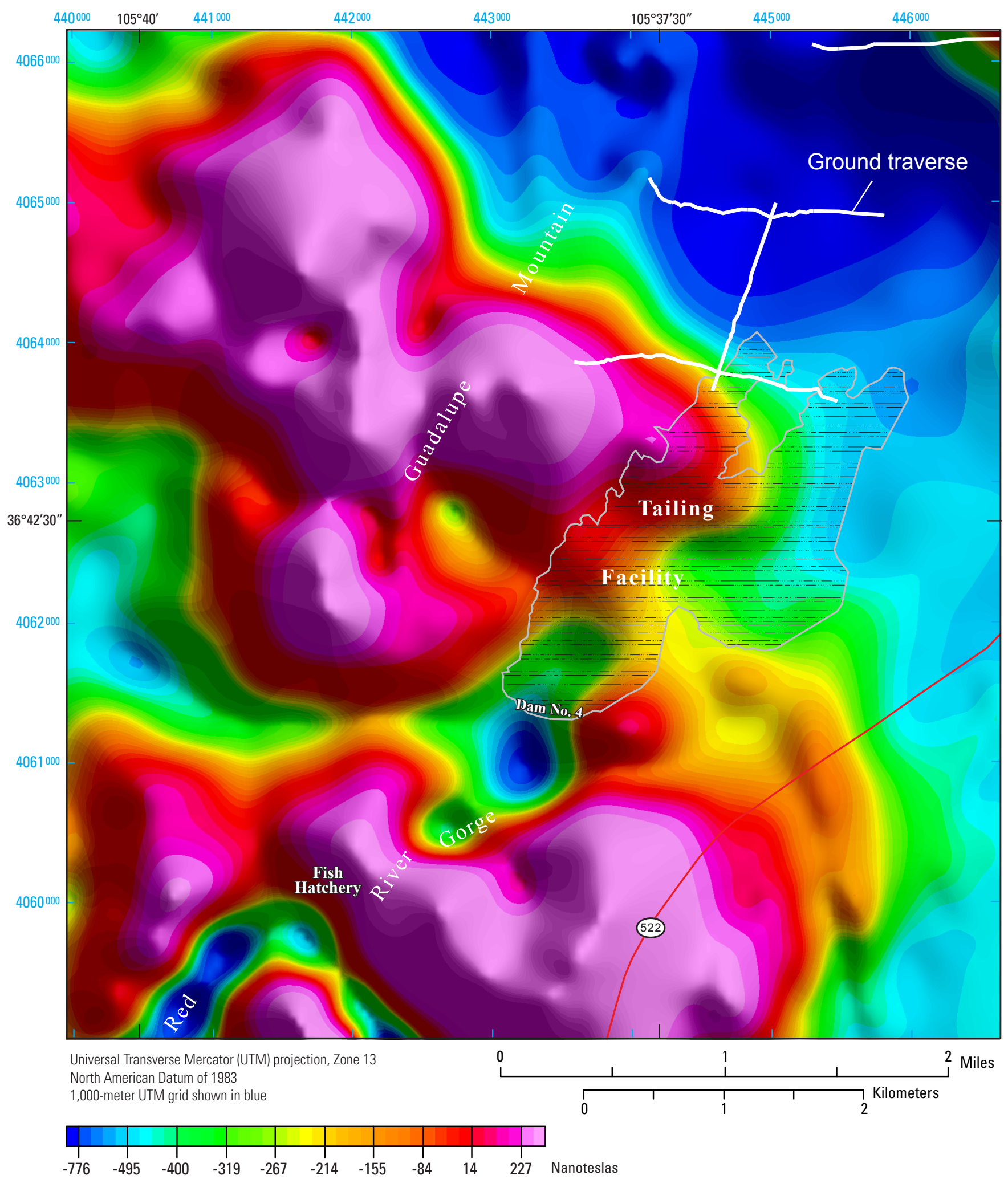

Figure 4. Aeromagnetic map of the study area after application of the reduction-to-pole transformation. Note the nonlinear color display to enhance variations. Image is illuminated from the northeast. Locations of ground magnetic traverses are shown by white lines. 

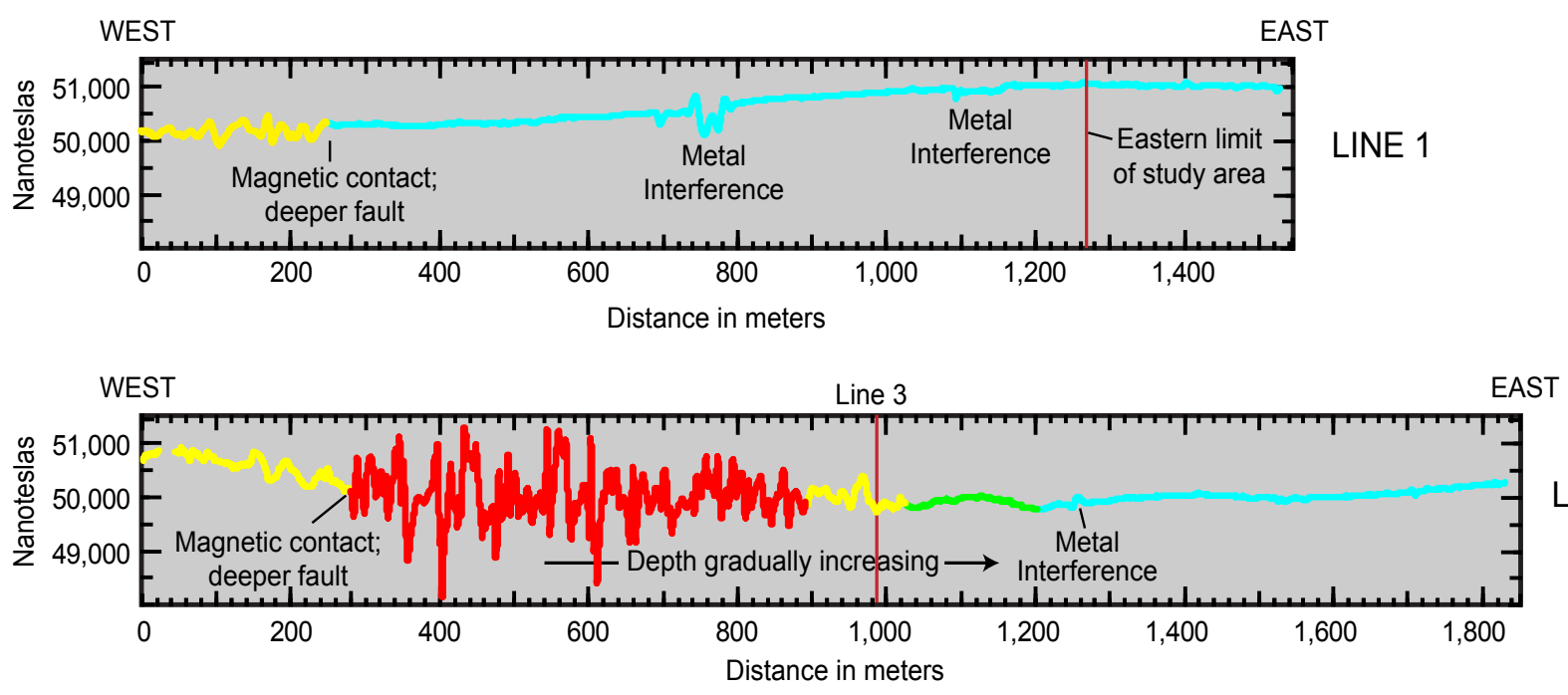

LINE 2

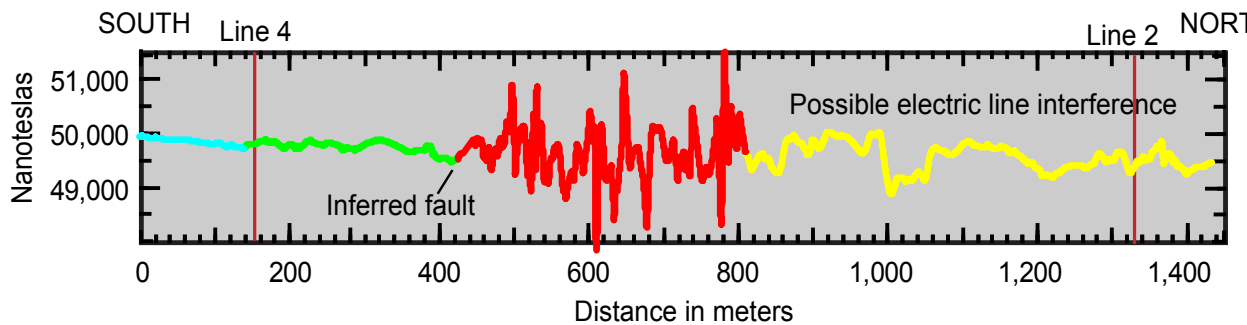

LINE 3

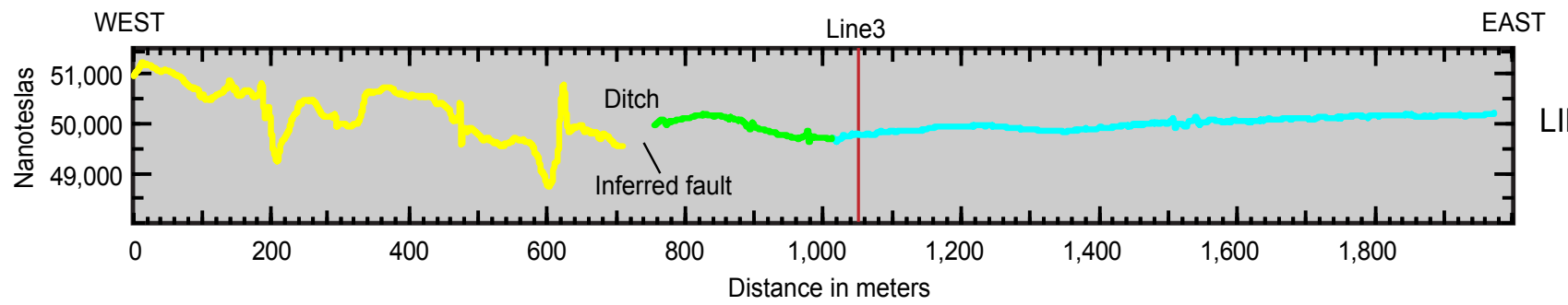

LINE 4

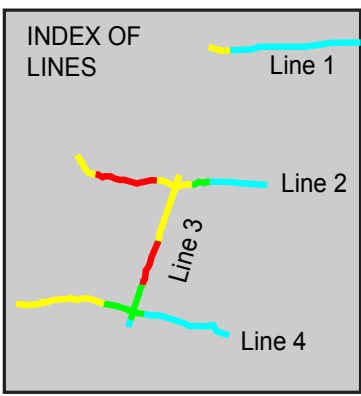

\section{EXPLANATION}

- Very high-frequency magnetic data High-frequency magnetic data

Low-frequency magnetic data

- Very low-frequency magnetic data

Figure 5. Data for four ground magnetic traverses acquired in 2014 (located on fig. 4). The relative frequency and amplitudes of the data curves are categorized. These features are a general indicator of the relative depths to volcanic rocks along the lines. Very highfrequency data indicate that magnetic rocks are at or very near the surface, whereas very low-frequency magnetic data indicate the rocks are much deeper ( $>25$ meters [m]) or not present at all. 


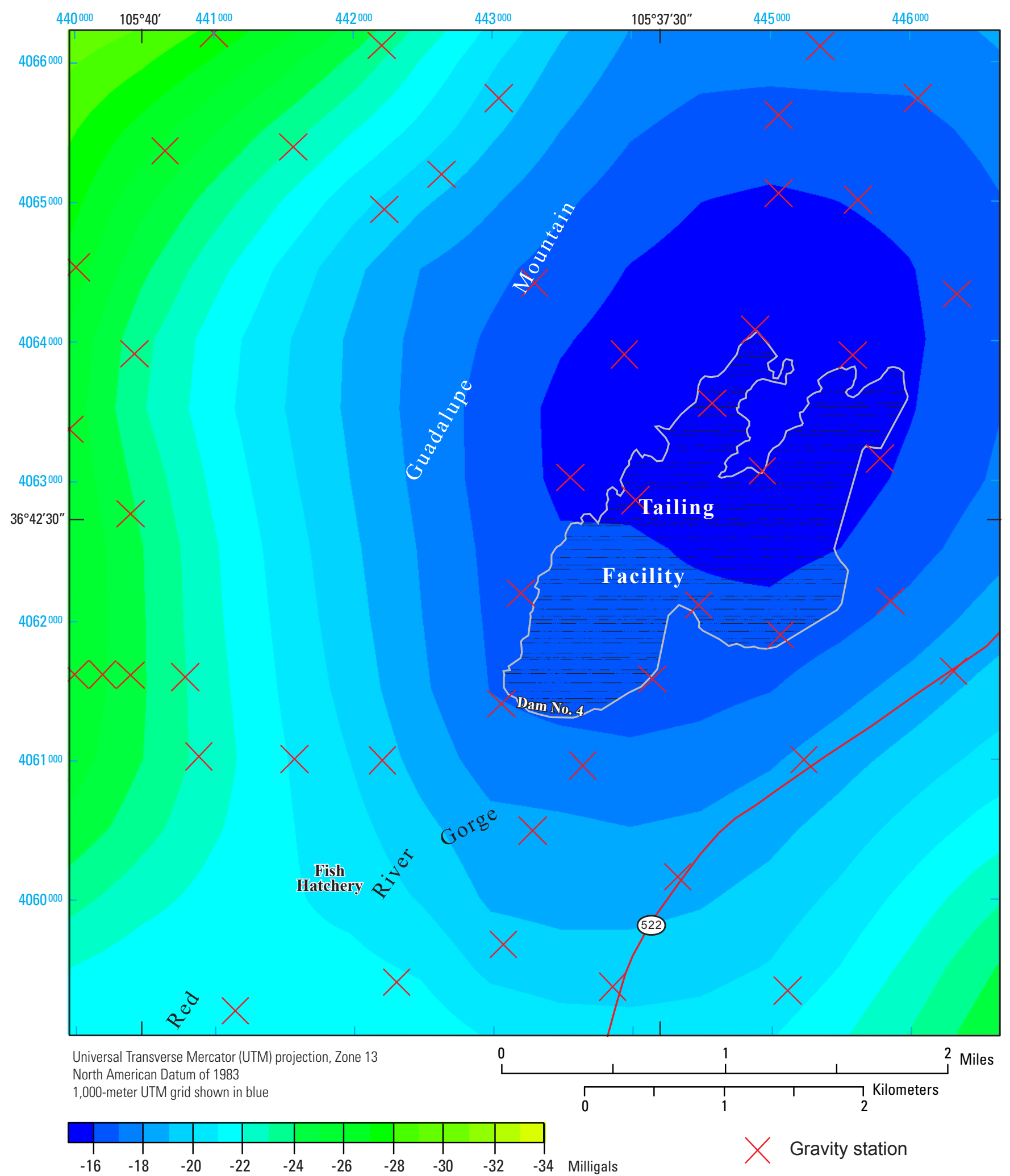

Figure 6. Gravity map of the study area after removal of an isostatic regional field showing the locations of gravity stations (X). 


\section{Methods}

\section{Magnetic Methods}

The reduced-to-pole aeromagnetic anomaly map (fig. 4) was the primary focus for qualitative and semiquantitative map interpretation. For the qualitative approach, patterns on the map corresponding to different volcanic units and their relative depths were recognized through comparisons to topography and to the geologic map. Volcanic rocks commonly exhibit characteristic anomaly patterns that are a function of their total magnetizations, their depth below the magnetometer, and their volume. Patterns associated with particular geologic units are recognized by comparing contacts on the geologic map and by comparing anomaly shapes to the topography. After volcanic units are recognized by certain anomaly patterns, their presence under cover can be mapped by following similar anomaly patterns into areas of cover.

Topographic features composed of magnetic rocks, such as hills and canyons, produce aeromagnetic patterns that reflect the form of the topography. These anomalies, called magnetic terrain effects, provide clues to the total magnetization and extents of volcanic rocks that underlie the topography (Grauch, 1987). Positive or negative correlations indicate normal- or reverse-polarity magnetizations, respectively. For example, areas of high and low values that correspond respectively to hills and valleys in the area (a positive correlation) indicate that the rocks in the near surface have normal-polarity total magnetizations. Similarly, areas on the aeromagnetic map that take forms that are inverted to topography (in other words, high values correspond to valleys and low values to hills) have a negative correlation, which indicates the rocks have reversepolarity magnetizations.

A way to assess magnetic terrain effects is to compute a theoretical magnetic field by modeling a digital elevation model of the area using a uniform magnetization. For this study, the magnetic-terrain field was computed using the program MBOXES (Phillips, 1997), which sums the magnetic effects of vertical prisms assigned to each grid interval of a digital elevation model (50-m grid interval for the study area). The top of each prism represents the elevation at each grid node of the digital elevation model. For this study, a total magnetization of 2.8 amperes per meter $(\mathrm{A} / \mathrm{m})$ in the direction of the Earth's present-day magnetic pole (inclination of $90^{\circ}$ ) was assigned to all prisms. This direction simulates the field that would be produced by rocks of uniform, normalpolarity magnetization after application of the reduction-tothe-pole transformation. In addition, the magnetic-terrain field is computed on the same 100-m draped surface to which the observed aeromagnetic data were continued. Thus, the reduced-to-pole aeromagnetic and magnetic-terrain maps can be directly compared (discussed in the Interpretations section of this report). Moreover, the total magnetizations of the rocks in areas that are correlated are proportional to the magneticterrain field so that relative magnetic intensities of the rocks can be estimated (Grauch, 1987). However, care must be taken in interpreting aeromagnetic lows that correspond to topographic lows because the lows may be caused by a lack of magnetization rather than reversed-polarity magnetic rocks. In these situations, an experienced interpreter may be able to resolve the ambiguity by inspecting amplitudes and details of the anomaly patterns.

Because aeromagnetic anomalies become broader and lower in amplitude as distance between the magnetometer and the source increases (Blakely, 1995), relative depths of magnetic rocks are recognized by the differing detail and amplitude expressed in the anomaly patterns. Anomaly patterns over shallow magnetic rocks can be recognized by patterns that look noisy with high-amplitude variations that occur over short distances. Patterns over deep magnetic rocks are recognized by patterns that look smooth with broad, low-amplitude variations. As a rule of thumb, amplitudes of anomalies decrease proportionally with respect to the inverse of the square of the distance $d\left(1 / d^{2}\right)$ from the magnetic source. The sampling interval, as well as differences in the distances between the magnetometer and the sources, must also be considered in comparing high-frequency anomalies between observations on the ground versus from aircraft. High-frequency anomalies with widths of tens of meters and very large amplitudes may be observed from data collected in ground traverses but are not detected in aeromagnetic maps constructed with a 50-meter grid interval because the sampling interval in the latter is too large.

For the semiquantitative approach, interpretations of contacts and faults were guided by the horizontal-gradient method (Cordell and Grauch, 1985; Blakely, 1995; Grauch and Hudson, 2007). This method relies on the principle that abrupt lateral contrasts in rock properties, such as those that occur at faults or steeply dipping contacts, correspond with the steepest gradients, or slopes, of their associated anomalies. Thus, mapping the steepest gradients in the aeromagnetic map show locations where these abrupt magnetic contrasts, or magnetic edges, occur. The steepest gradients are located by computing the local maxima of the horizontal-gradient magnitudes (HGM) of reduced-to-pole magnetic data. The procedure is analogous to taking a first derivative to find the inflection point of a curve. The HGM is computed as a separate grid (discussed in the Interpretations section of this report). Corresponding magnetic edges are located along HGM maxima that appear as ridges, guided by anomaly shapes observed in the aeromagnetic map in comparison to expected magnetic terrain effects.

Although many magnetic edges detected from HGM grids correspond directly with underlying faults, the interpretation is not always straightforward. First, steep gradients can 
be caused by steeply dipping surfaces other than faults, such as dipping beds truncated by erosion, lithologic rather than fault-related contacts, and high-relief topography. Although the nature of magnetic edges usually becomes apparent during interpretation, the origins of some may remain ambiguous. Second, mapping the surface projections of faults from magnetic edges is affected by the dip of the interface and the location of the magnetic contrast at depth along the interface. Where dip is less than vertical, the maximum of the HGM migrates downdip farther away from the surface projection as depth to the magnetic contrast increases (Grauch and Cordell, 1987; Grauch and Hudson, 2007). The offset increases as a function of shallowing dip and increasing depth to the magnetic contrast. For example, at depths of $200-500 \mathrm{~m}$ and a dip of $60^{\circ}$, maximum offsets can be approximately $200-450 \mathrm{~m}$ (Grauch and Hudson, 2007).

\section{Gravity Methods}

The large spacing between gravity stations relative to the size of the study area allows for regional interpretation only. Regional interpretations rely on recognizing large gravity gradients that slope into gravity lows to recognize basins filled with low-density sediments, typical of the Rio Grande rift (Cordell, 1978). Relatively steep gravity gradients indicate basin margins, and the gravity minima indicate the deepest parts of the basins.

Two-dimensional gravity modeling is used in this study to address simple questions where there is ambiguity about the composition and thickness of basin fill. The modeling employs simple polygonal shapes assigned with densities estimated for different rock types to test various end-member scenarios. Densities assigned to the model for this study area are estimated differently for Precambrian basement rocks, basin-fill sediments, and volcanic rocks of Guadalupe Mountain. For simplicity, the density of modeled basement rock is assumed to be $2,670 \mathrm{~kg} / \mathrm{m}^{3}$, which is an average crustal density for the Earth, a common density used in modeling and data reduction, and is measured by density logs in boreholes in the Albuquerque Basin to the south (Grauch and Connell, 2013). Densities for basin-fill sediments follow a density-depth function derived from borehole density logs in the rift in the vicinity of Albuquerque (Grauch and Connell, 2013). In this function, densities of the basin-fill sediments are estimated as $2,170 \mathrm{~kg} / \mathrm{m}^{3}$ for the top $1.25 \mathrm{~km}$ and $2,300 \mathrm{~kg} / \mathrm{m}^{3}$ to $2.75 \mathrm{~km}$ depth. Nettleton profiling was used to estimate the bulk density of rocks contained within Guadalupe Mountain. Nettleton profiling is a standard technique (Blakely, 1995) wherein different densities are tested during processing of gravity data collected in a traverse over hilly topography. The density that results in the least correlation between gravity and topographic profile data is considered to be the average bulk density for the rocks composing the hills. This approach gave a bulk density of $2,450 \mathrm{~kg} / \mathrm{m}^{3}$ for rocks underlying the main part of the mountain.

\section{Interpretations}

Figure 7 shows the reduced-to-pole aeromagnetic map overlain by interpretative lines and annotations regarding the nature and extent of volcanic rocks, their relative depths, inferred contacts between them, and conjectured locations of faults. The interpretations were guided by comparisons among the aeromagnetic map, a map of the computed magneticterrain field (fig. 8), the geologic map (fig. 9), and the HGM of the reduced-to-pole aeromagnetic map (fig. 10). For comparison, the same interpretative lines and annotations are overlain on all four maps (figs. 7-10).

General inspection and comparisons of the maps indicate that the Quaternary deposits are not significant sources of aeromagnetic anomalies at the detection limit of the current aeromagnetic survey. Instead, observed aeromagnetic anomalies arise primarily from the volcanic units mapped throughout the area: andesitic volcanic deposits of Hatchery volcano (Tvh), dacite of Red River (Tvr), and predominantly trachydacite of Guadalupe Mountain (Tagn, Tags, and Tag). Aeromagnetic interpretations regarding these volcanic rocks and contacts and faults that juxtapose them are discussed in the following three sections. Discussion of the aeromagnetic interpretations in relation to gravity interpretations of the regional rift-basin underlying Guadalupe Mountain is included in the fourth section.

\section{Volcanic Deposits of Hatchery Volcano-Tvh- and Andesite of Red River-Tvr}

Exposed areas mapped as Tvh generally correspond to strong positive aeromagnetic anomalies along the Red River (figs. 7 and 9), indicating that Tvh is strongly magnetic. Anomaly highs and lows positively correlate with the topographic highs and lows across the Red River Gorge southwest of the Red River fault zone (figs. 7 and 8), indicating normal-polarity magnetization. Strong positive anomalies also correspond to exposed areas of Tvr, but because Tvh underlies Tvr in these areas, it is ambiguous whether anomalies are caused by Tvh alone or a combination of Tvh and Tvr. Strong, normal-polarity magnetization for Tvh is supported by rock magnetic-property measurements of exposed andesite near the fish hatchery (M. Hudson, USGS, unpub. data, 2013). Similar measurements for Tvr in the same area show an induced component similar in magnitude to that of Tvh, but measurements of remanent magnetization were obscured by local remagnetization caused by lightning strikes.

Figure 7 (following page). Interpretations overlain on the aeromagnetic map of figure 4 with an explanation of lines and symbols. Tailing Facility, highway, and fault zones are depicted as in figure 4. Locations of ground magnetic traverses are coded according to inferred relative depths based on anomaly patterns (fig. 5). Models for profile A-A' are shown in figure 12. 


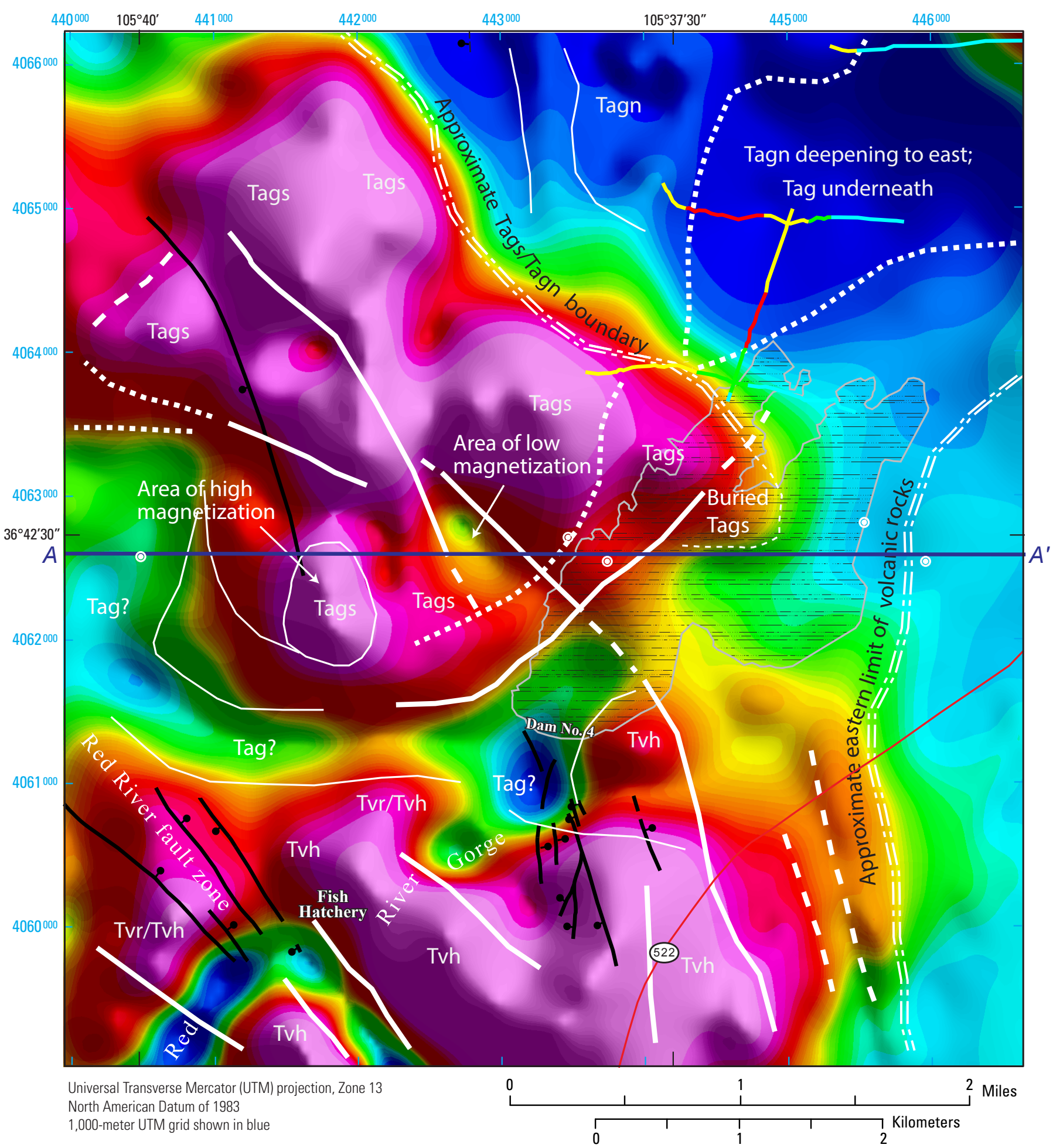

EXPLANATION

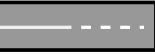

Magnetic contact inferred to be a lithologic or faul contact between different volcanic rocks, dashed where uncertain

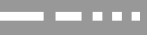

$= \pm \sqrt{2}= \pm$
Inferred normal fault, dashed where uncertain, dotted where deeply buried

Inferred major boundary between different rock types at depth, approximately located

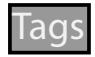

Geologic unit (from fig. 3) interpreted to represent aeromagnetic anomalies between contacts or faults

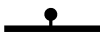

Mapped fault from geologic map, only where confirmed; ball on downthrown side

Location of geophysical profile model

Location of well used to constrain geophysical profile model 


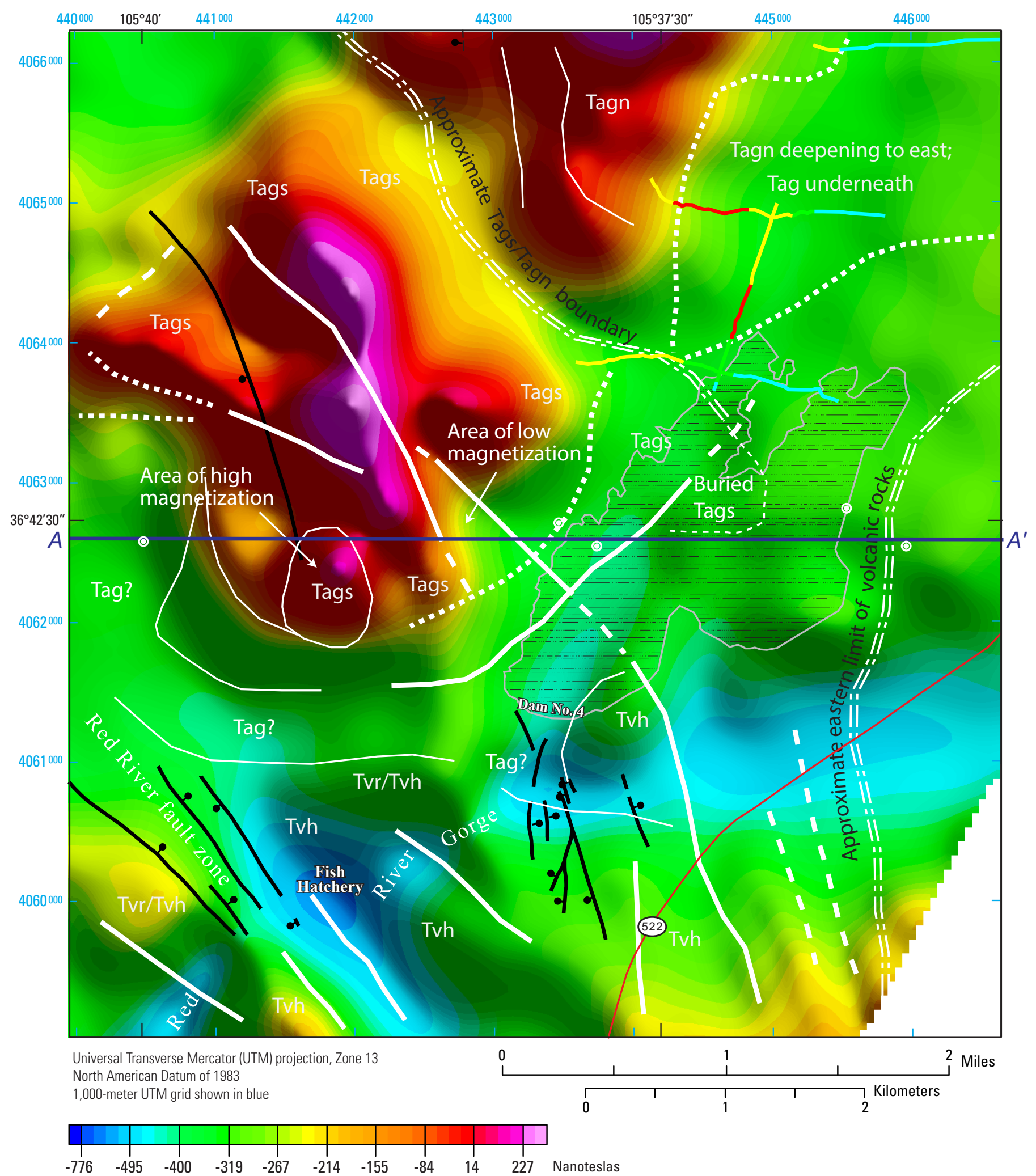

Figure 8. Computed magnetic-terrain field for the study area using a uniform, normal-polarity (vertical inclination) total magnetization of 2.8 amperes per meter $(\mathrm{A} / \mathrm{m})$. Color display is the same as figure 4. Interpretative lines and annotations are from figure 7. 


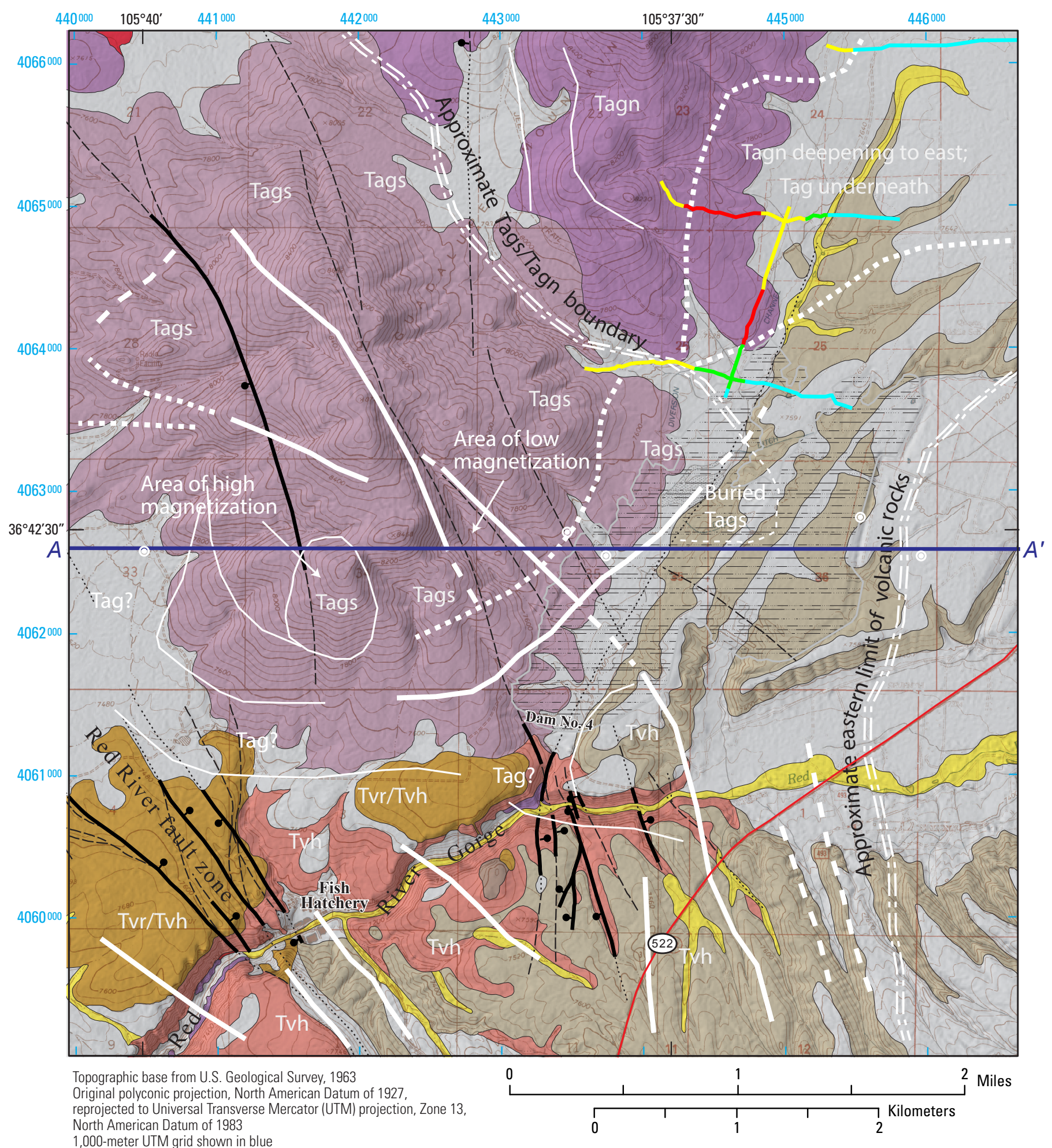

Figure 9. Geologic map of study area (fig. 3) overlain by interpretative lines and annotations of figure 7. 


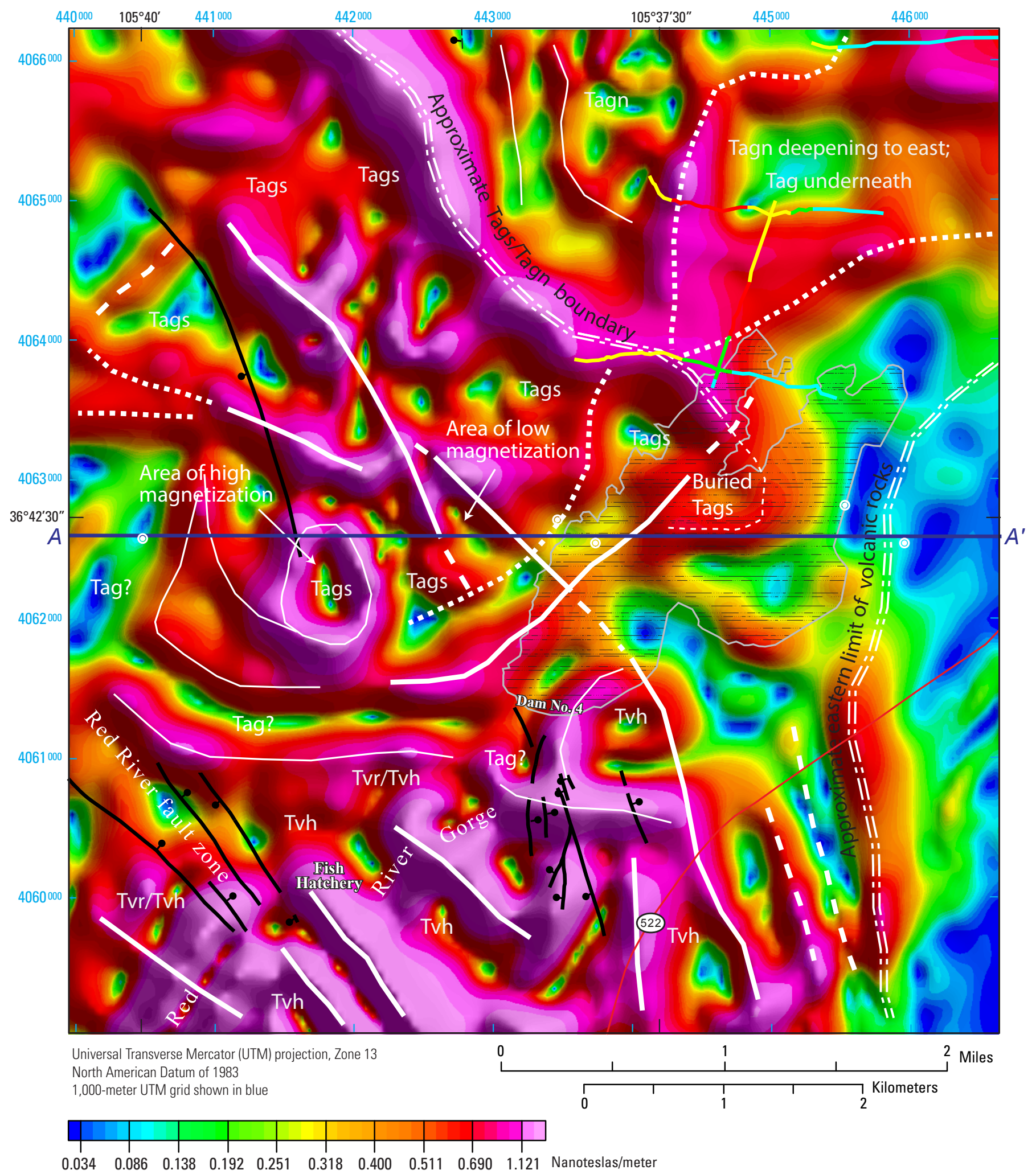

Figure 10. Horizontal-gradient magnitude (HGM) of the reduced-to-pole aeromagnetic data. Magnetic edges that may correspond to faults or lithologic contacts are inferred along and extrapolated between ridges. Interpretative lines and annotations are from figure 7. 
East of the Red River fault zone, the area of strong positive aeromagnetic anomalies continues southward of the exposures of Tvh that are on the south side of the Red River, suggesting that Tvh extensively underlies the Lama Formation (QT1) in the southern part of the study area. Considering that the anomaly patterns where Tvh is exposed and extrapolated under cover are very similar in character, we conclude that the Lama Formation is thin in this area.

Relatively low magnetic field values extend over a wide area within and north of the Red River Gorge on either side of an unnamed fault zone where it crosses the Red River Gorge south of Dam No. 4 (fig. 7). Volcanic units Tvh, Tvr, and Tags are exposed in the area of the low values (fig. 9), which contradict their associations with high values elsewhere. Possible reasons for the area of low aeromagnetic values may be (1) primary differences in magnetizations of the rocks from one area to another; (2) hydrothermal alteration that destroyed the magnetizations of the rocks; or (3) an underlying unit that has strong, reversed-polarity magnetization with thin Tvh and Tvr on top. Differences in primary magnetizations of the volcanic units are possible but seem unlikely that all three units would show a difference in magnetization in this one area. Evidence for secondary hydrothermal alteration in the area is lacking, although primary oxidation of magnetic minerals associated with vent areas is common across the area mapped as Tags. Alternatively, local post-emplacement alteration of the volcanic sequence may simply be concealed. A candidate for a reversed-polarity, magnetic volcanic unit underlying thin Tvh and Tvr is evident from a small exposure of the trachydacite of Guadalupe Mountain (Tag) near the fault zone. This unit is inferred from aeromagnetic data to the north (discussed in the next section) as an older deposit, compositionally similar to erupted lavas of Guadalupe Mountain.

\section{Trachydacite of Guadalupe Mountain-Tagn, Tags, Tag}

Comparisons of the aeromagnetic map (fig. 7) to the magnetic-terrain model field (fig. 8) over Guadalupe Mountain show a general positive correlation on the southwest and negative correlation on the northeast. Where patterns in the observed aeromagnetic map correspond to those of the magnetic-terrain field, we infer that rocks composing the topography are the sources of the aeromagnetic anomalies. The positive and negative correlations indicate the rocks have different polarities, and thus different ages, despite the similarity in rock type. As a consequence, the trachydacites are mapped separately on north (Tagn) versus south (Tags) Guadalupe Mountain.

Positive correlation with the magnetic-terrain model field extends across most of south Guadalupe Mountain, most notably on the southwest side where steep gradients in both maps are oriented similarly. A general positive correlation is also evident along the northerly trending ridges that correspond to the high ridges of the mountain. Within the area of positive correlation, the extremely high magnetic values suggest that the rocks mapped as Tags are very magnetic with normal-polarity magnetization. This inference is supported by measurements at one site on the northwest side of the mountain (M. Hudson, USGS, unpub. data, 2013). Therefore, these magnetic rocks are the bulk of the volume of rock underlying south Guadalupe Mountain.

Positive correlations between the aeromagnetic and magnetic-terrain field maps are not present everywhere over south Guadalupe Mountain. Strong, positive aeromagnetic anomalies extend farther out from the mountain than predicted by the magnetic-terrain model on the southeast and northwest sides of the mountain. In these extended areas, the outer limits of the positive aeromagnetic anomalies generally locate the perimeter of the large volume of magnetic rocks underlying south Guadalupe Mountain in the subsurface (fig. 7). Except for one area, positive anomalies in the extended areas generally show broad shapes with low amplitudes, consistent with the expression of the contact of a large volume of rocks at depth. Where this aeromagnetic expression extends under areas of mapped Quaternary units on the east side of south Guadalupe Mountain (labeled as buried Tags), the top of the subsurface volume of Tags may be at some depth $(>100 \mathrm{~m})$ below the surface. The one exceptional area surrounds the high peak at the southernmost part of Guadalupe Mountain, labeled "area of high magnetization." In this area, positive observed anomalies show higher amplitudes than predicted by the magnetic-terrain field model. The area of higher values abuts the area of low magnetic values discussed in the previous section, attesting to a large magnetic contrast between rocks at the contact between these two areas.

The wide area of low magnetic field values on the aeromagnetic map on the northeastern part of Guadalupe Mountain (blue colors on fig. 7) shows general negative correlation between the aeromagnetic and magnetic-terrain model map (fig. 8). In this area and extending out of the study area to the north and northeast, high-amplitude negative anomalies in the observed data indicate that rocks of Tagn are magnetic and reversely polarized. In detail, the inverse correlations between anomaly shapes in the two maps are only fair, suggesting that magnetic intensities of the rocks are actually quite variable.

Analogous to observations for Tags to the south, the negative aeromagnetic anomalies interpreted as Tagn extend farther east than predicted from the magnetic-terrain field model, extending east of the northeasterly dashed interpretative line following the east side of the mountain (near longitude $105^{\circ} 37^{\prime} 30^{\prime \prime}$ ) on figures 7 and 8 . East of this interpretative line, a large-amplitude, broad negative anomaly extends to the eastern boundary of the study area. The broad negative anomaly is relatively featureless, without any obvious correlation to the magnetic terrain field (fig. 8), suggesting a large volume of magnetic, reversed-polarity rocks is located at 
depth in the subsurface $(>100 \mathrm{~m})$. Given the somewhat circular shape of the broad anomaly and that the anomaly minima occurs away from the vent areas mapped near the peaks of Guadalupe Mountain, we speculate that this inferred volume of rock represents an older volcanic edifice that predates the formation of Tags and Tagn. If so, eruptions of the trachydacites at Guadalupe Mountain must have spanned two reversals of the Earth's magnetic field, such that Tag erupted during a reversal, and then Tags erupted during a time of normal polarity, and finally Tagn erupted during another reversal. Preliminary ${ }^{40} \mathrm{Ar} /{ }^{39} \mathrm{Ar}$ geochronology suggests that these lavas have eruption ages near $5 \mathrm{Ma}$ (Thompson and others, 2011), compatible with a reverse-normal-reverse sequence of events in the magnetic polarity time scale between 5.3 and $5.1 \mathrm{Ma}$ (Ogg and Smith, 2004).

If this hypothesized, older reversed-polarity unit (Tag) is widespread in the subsurface, it could clarify some unexplained areas of low magnetic values such as the one south of Dam No. 4, which was already discussed. It could also explain a generally elongated area of moderately low magnetic values that extends westward from Dam No. 4 and wraps around the southern and southwestern edges of Guadalupe Mountain (labeled Tag?). A roughly similar but much more subdued area of low values is apparent in the magnetic terrain field (fig. 8), suggesting a very general correlation with terrain. However, the observed aeromagnetic low is larger in amplitude than that of the magnetic terrain field, indicating that the rocks in this area have either normal-polarity total magnetization less than $2.8 \mathrm{~A} / \mathrm{m}$ (the magnetization used to compute the magnetic terrain field) or have a reverse polarity. The shape of this elongated low is reminiscent of a channel, suggesting that it can be explained by an underlying paleochannel filled with weakly magnetic sediments or an old lava flow that was channeled around the southern limit of the volcano. Alternatively, the low is explained by underlying, reversely polarized Tag that is blanketed by a thin cover of normal-polarity Tags that correspond to the margins of the Tags volcano.

In the southern part of Guadalupe Mountain, a fault interpreted from the aeromagnetic data forms a triangular area with the northern extension of the fault zone near Dam No. 4, north of Red River. Within the triangular area, a small area of lower magnetic values (labeled "area of low magnetization") does not correspond to the shapes expected from the magneticterrain field model (fig. 8). The low values suggest the presence of a volume of rock that is much lower in magnetization than surrounding rocks or rocks that have reverse polarity. The location of the area near the apex of the triangle formed by the mapped and inferred faults suggests that the explanation has a relation to faulting. Fault-related possibilities to explain the lower magnetizations are (1) differences in thickness of overlying Tags on top of a horst of rocks of differing magnetization, (2) hydrothermal alteration guided by the faults that decreased the magnetization of a significant volume of the rocks, and (3) an area that is significantly disrupted by chaotic fault blocks or composed of landslide material related to faulting. The possibilities remain speculative because evidence for them may be covered.

Exposures of Tagn are mapped within the broad negative anomaly hypothesized as a buried Tag volcano (figs. 7 and 9) and just east of the interpretative line near $105^{\circ} 37^{\prime} 30^{\prime \prime}$. These rocks apparently have no expression in the aeromagnetic data. They may be too thin to be detected by the aeromagnetic survey or have much lower magnetizations than those of Tagn to the west or those inferred for Tag in the subsurface. Because the ground magnetic data are much more sensitive to shallow magnetic sources than he aeromagnetic data, observations of the frequency content of the ground magnetic data from figure 5 can be used to evaluate the presence of very shallow volcanic rocks throughout the area of the broad negative anomaly. The different frequency contents from the ground magnetic traverses are color coded (fig. 5) and plotted on the aeromagnetic and geologic maps (fig. 7 and 9). The areas of high-amplitude, high-frequency anomaly patterns indicate very shallow volcanic rocks, whereas the broader, lower amplitude anomalies indicate deeper volcanic rocks. Maximum amplitudes of the anomalies range to approximately 2,000 nanoteslas. Considering the aeromagnetic observation surface is almost $100 \mathrm{~m}$ higher than the ground magnetic traverse, the amplitudes of these anomalies observed from the air would be reduced by four orders of magnitude, suggesting that these volcanic rocks are not as magnetic as the bulk of Tagn to the west. Consistent with the earlier observation of variable correlation between the magnetic terrain model and observed aeromagnetic data to the west of $105^{\circ} 37^{\prime} 30^{\prime \prime}$, the rocks east of this line may represent a volcanic flow that formed in conditions unfavorable for acquiring a strong remanent magnetization.

Abrupt differences in frequency contents of the groundmagnetic data curves from high-frequency to low-frequency data (fig. 5) indicate places where shallow volcanic rocks terminate or are fault offset to lower depths. Such differences are observed at 420-m distance on line 3 and inferred at 740-m distance on line 4, coincident with a wide ditch related to the Tailing Facility. Faults are inferred at these locations because the difference in frequency content is large. Differences in frequency content on the west sides of lines 1 and 2 are not quite as large but coincide with the locations of more regional, presumably deeper, faults inferred from the aeromagnetic data (labeled as "Magnetic contact; deeper fault"). A gradual change from very high frequency to low frequency is observed from approximately $550-\mathrm{m}$ to $1,200-\mathrm{m}$ distance on line 2 . The gradual decrease in frequency suggests a gradual deepening of the top of these volcanic rocks to the east. They probably reach at least 25-m depth (or are no longer present) underneath deposits of QT1 east of 1,220-m distance. The faults inferred from the ground magnetic traverses correlate well with deeper faults inferred from the aeromagnetic data (dotted lines on fig. 7). 


\section{Faults and Other Contacts}

The magnitude of the horizontal gradient (HGM) of the reduced-to-pole aeromagnetic grid was computed in a moving 3 -point window across the grid, shown in figure 10. Many of the ridges on the HGM map indicate contacts between rocks of differing magnetizations (magnetic contacts), which commonly occur at intrusive or depositional contacts or at normal faults. Faults are inferred where the contacts are linear and supported by differences in anomaly patterns and plausible geologic relations. In some cases, gradients evident in the aeromagnetic map have indefinite correspondence to HGM ridges or are difficult to connect. These uncertain contacts are shown as dashed lines on the interpretative overlay. Dotted lines are drawn across very wide or subdued ridges, which indicate the contacts are likely deeper than other magnetic contacts in the area.

Some HGM ridges correspond to gradients in the magnetic-terrain field model. Because they correspond to topography, these HGM ridges simply may reflect steep topographic slopes especially if they are curved, or reflect faults if they are linear. For example, HGM ridges surrounding the southwest side of Guadalupe Mountain likely represent steep topographic slopes because they are curved and match gradients in the magnetic-terrain field map (figs. 7 and 8). However, the west-northwest trending gradient on both maps on the west side of Guadalupe Mountain is linear and may be a fault. If so, the mapped fault that crosses this inferred fault just north of the area of high magnetization must be younger because it is evident at the surface but the geophysically inferred fault is not. Other HGM ridges align with mapped faults or cross the trends of topographic features. These ridges represent sharp juxtaposition of rock types having differing magnetizations as opposed to interfingering relations. Where these HGM ridges are linear, they likely represent faults. Examples include several northwest-trending ridges that align with the southeastern extension of the Red River fault zone. An inferred northerly to northwesterly extension of the fault zone near Dam No. 4 crosses through the middle of the Tailing Facility. It is inferred on the basis of an alignment of linear gradients that all indicate differences in magnetization, but the magnitude of the differences vary along strike. Therefore, it is better expressed in the aeromagnetic data (fig. 7) than in the HGM map (fig. 10). The depth to this fault is not well constrained.

A prominent HGM ridge marks the boundary between the magnetic highs associated with Tags and the magnetic lows associated with Tagn in the southern and northern parts of Guadalupe Mountain, respectively. The boundary is an expression of where the bulk difference in magnetizations occurs at contacts between these two rock types. In detail, Tagn may have some flows that extend across the boundary to the southwest on top of Tags, or parts of the older Tags volcano may have been left uncovered by the younger Tagn flows.

\section{Basin Shape and Thickness}

In figure 11, the gravity map of figure 6 is overlain by the interpretative lines and annotations from figure 7. The figure shows a large, oval-shaped region of low-gravity values elongated in a northeasterly direction and centered over the eastern side of Guadalupe Mountain. The large amplitude of the gravity low (approximately 15 milligals) and its location within the Rio Grande rift (fig. 2) suggests the gravity low is an expression of a subbasin of the rift. The color contours that define gravity gradients surrounding the lowest gravity values also locate the subbasin boundaries, which may represent a series of major normal faults that drop the basin floor down toward the gravity minima. Data coverage for the gravity map (fig. 6) is not dense enough to define the locations of these faults. However, mapped and inferred faults from the aeromagnetic data, such as the Red River fault zone and the unnamed fault zones to the east, have similar northwesterly orientations as do the gravity contours on the southwestern side of the gravity low. These faults may be expressions of the subbasin boundaries.

Because Guadalupe Mountain straddles the western side of the gravity-defined subbasin, it is unclear how much of the subbasin is filled with volcanic rocks and how much is filled with rift sediments of the older Santa Fe Group. To address this question, we constructed simple two-dimensional gravity models (fig. 12) using the geologic map (fig. 3) and several wells for constraints. In addition, we know that Guadalupe Mountain volcanic rocks are present as far east as $12-\mathrm{km}$ distance along the profile (figs. 7 and 12). Densities for the model were assigned on the basis of estimations described in the Gravity Methods section.

Two alternate models of the thickness of Santa Fe Group (Tsf) and trachydacites of Guadalupe Mountain (Tags/Tag) are shown in figure 12. In figure $12 \mathrm{~A}$, the volcanic rocks were modeled with minimum thickness, as thin as the well constraints allowed, then the thickness of Tsf below it was adjusted so that the modeled curve generally matched the observed curve. In figure $12 B$, the volcanic rocks were modeled with much greater thickness by several orders of magnitude. To accommodate this increased mass and still fit the observed gravity curve, the basin had to be deepened significantly, reaching almost to sea level. Although the thickness of Tsf is not increased significantly from the first scenario, the second scenario requires a geologic history that includes (1) almost $2.4 \mathrm{~km}$ of basin subsidence before $5 \mathrm{Ma}$ and (2) eruptions over a period of less than 2 Ma of sufficient volume to deposit over 1-km thickness of lavas in the subbasin. These rates seem high for the region but not unreasonable. The exact ratio of volcanic-to-sediment thickness under Guadalupe Mountain is probably somewhere between the two geophysical models. The important conclusion is that both rock types must be present. 


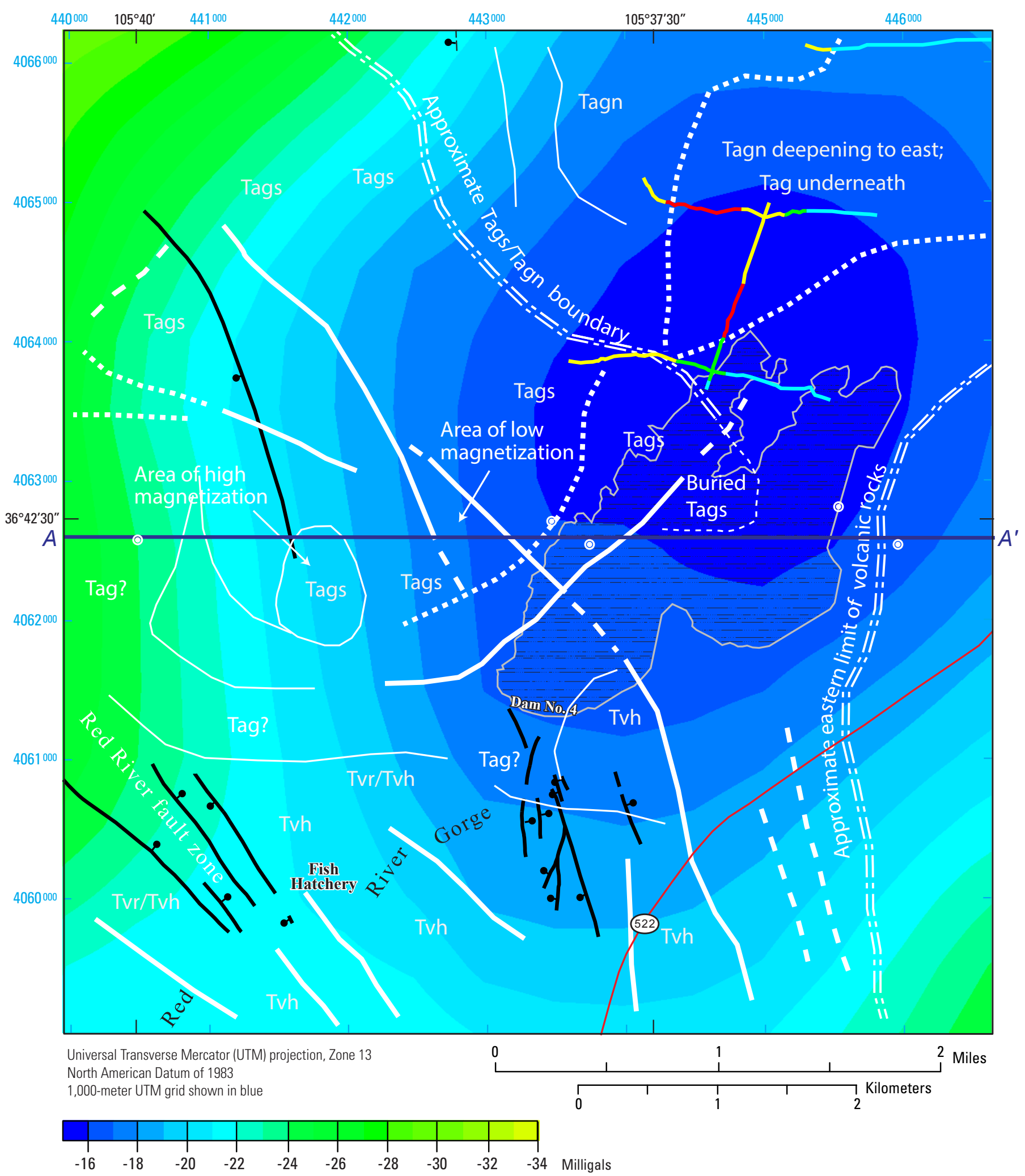

Figure 11. Gravity map from figure 6 overlain by interpretative lines and annotations of figure 7 . 
(A) $A+A^{\prime}$
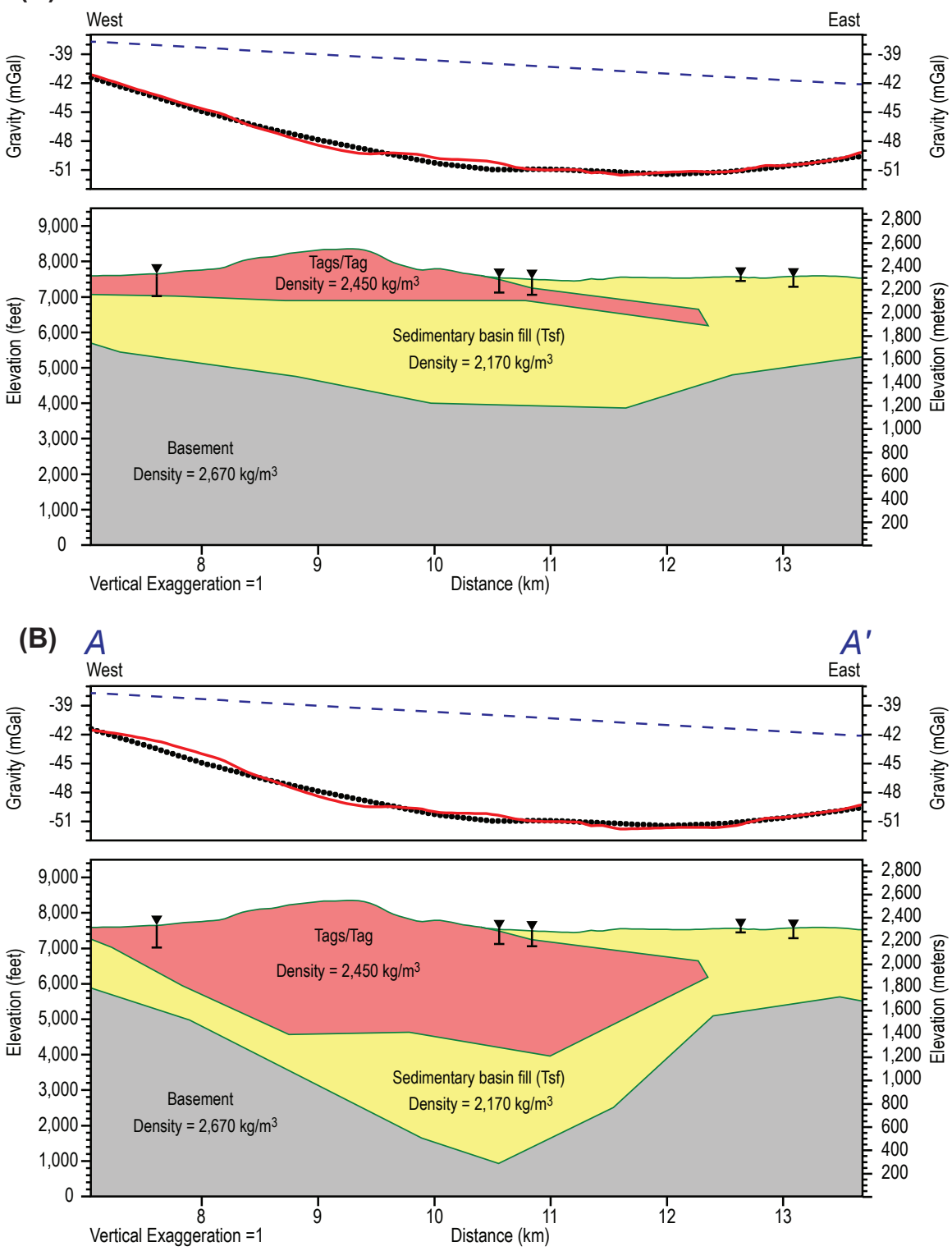

Figure 12. Alternative gravity models across the west-to-east profile $A-A^{\prime}$ (located on figures 7-11) to test alternate scenarios of the thickness of Guadalupe Mountain volcanic rocks overlying Tertiary Santa Fe Group sediments (Tsf). Geologic units Tags and Tag are described in figure 3B. Quaternary deposits are not shown. $\mathrm{km}$, kilometer; $\mathrm{mGal}$, milligal; $\mathrm{kg} / \mathrm{m}^{3}$, kilogram per cubic meter. 


\section{Preliminary Geophysical Interpretations of Subsurface Geology-Questa Mine Tailing Facility and Guadalupe Mountain}

\section{Summary}

Aeromagnetic data, regional gravity data, and data from four ground magnetic traverses were used along with geologic mapping and a few well constraints to interpret regional subsurface features in the vicinity of the Tailing Facility of the Questa Mine near Guadalupe Mountain. Aeromagnetic data provided the most comprehensive dataset for interpretation of the regional setting of the subsurface. Aeromagnetic data were first transformed using a standard reduction-to-the-pole operation. Interpretations were accomplished by comparing the reduced-to-pole data to a hypothetical model of the effects of uniformly magnetized terrain, geologic contacts, and computation of the horizontal gradient magnitude (HGM) of the data.

The interpretations focused on mapping rock types and their relative volumes in the subsurface and on locating the contacts, including faults, between them. To help visualize the interpretations in context of siting drill holes in the vicinity of the Tailing Facility, the interpretative overlay of figure 7 is overlain on the satellite image of the study area in figure 13. The main points from the interpretation are as follows.

- The primary sources of the aeromagnetic anomalies are the volcanic rocks of the study area: andesitic volcanic deposits of Hatchery volcano (Tvh), dacite of Red River (Tvr), and trachydacite of Guadalupe Mountain (Tagn, Tags, and Tag).

- Strong aeromagnetic expression of Tvh continues to the south of the Red River Gorge, suggesting that Tvh is shallow below sedimentary deposits of the Lama Formation (QTl) that are mapped at the surface.

- Trachydacites of Guadalupe Mountain are very magnetic but have magnetizations of normal polarity on the south and reverse polarity on the north, suggesting the rocks in these two areas generally have different ages. Strong aeromagnetic highs with positive correlation to terrain over southern Guadalupe Mountain are mapped as Tags, whereas strong aeromagnetic lows with generally negative correlation to terrain over northern Guadalupe Mountain are mapped as Tagn. The boundary between these two rock types is marked by a prominent HGM ridge that generally follows a topographic saddle that crosses the mountain.

- Aeromagnetic anomalies associated with both Tags and Tagn extend farther out from the mountain front than predicted by the magnetic-terrain model, suggesting that they extend out under cover in these areas.
- A large broad aeromagnetic low that extends east of the area mapped as Tagn suggests that additional Guadalupe Mountain lava flow deposits with reversepolarity magnetization lie at depth (Tag). If one infers that the circular nature of the anomaly and its minima located east of Guadalupe Mountain are indicative of a buried volcano, the additional deposits are likely to be older than both Tagn and Tags. Preliminary age dating compared to magnetic-polarity events near $5 \mathrm{Ma}$ suggests this relation is geologically feasible.

- Ground magnetic traverses over the area suggest that exposed volcanic rocks at the surface in the area of the broad anomaly associated with Tag are not detected in the aeromagnetic data because they have much lower magnetization than the deeper rocks. The ground magnetic data also suggest these near-surface flows are fault-bounded on the west and deepen gradually to the east.

- Several aeromagnetic lows that do not correspond to geologic mapping or to the expected effects of terrain indicate areas where rocks of lower magnetic intensity or reverse-polarity magnetization (or possibly sediments) are present underneath Tags. The areas are located near the southern margin of Guadalupe Mountain, and are labeled as "area of low magnetization," and "Tag?".

- Several faults are inferred from the aeromagnetic data, coded by uncertainty or by depth on figure 13 (explained on figure 7). Several of the inferred faults align with or extend known fault zones. An inferred northerly to northwesterly extension of the unnamed fault zone near Dam No. 4 crosses through the middle of the Tailing Facility. It is inferred on the basis of an alignment of linear gradients that all indicate differences in magnetization but the magnitudes of the differences vary along strike.

- Examination of the aeromagnetic interpretations in comparison to the gravity map shows that Guadalupe Mountain straddles the western margin of a subbasin of the Rio Grande rift. Two alternate profile models of the gravity data indicate that both volcanic rocks and underlying sediments of the Tertiary Santa Fe Group must be present under Guadalupe Mountain. However, their thicknesses are poorly constrained. 


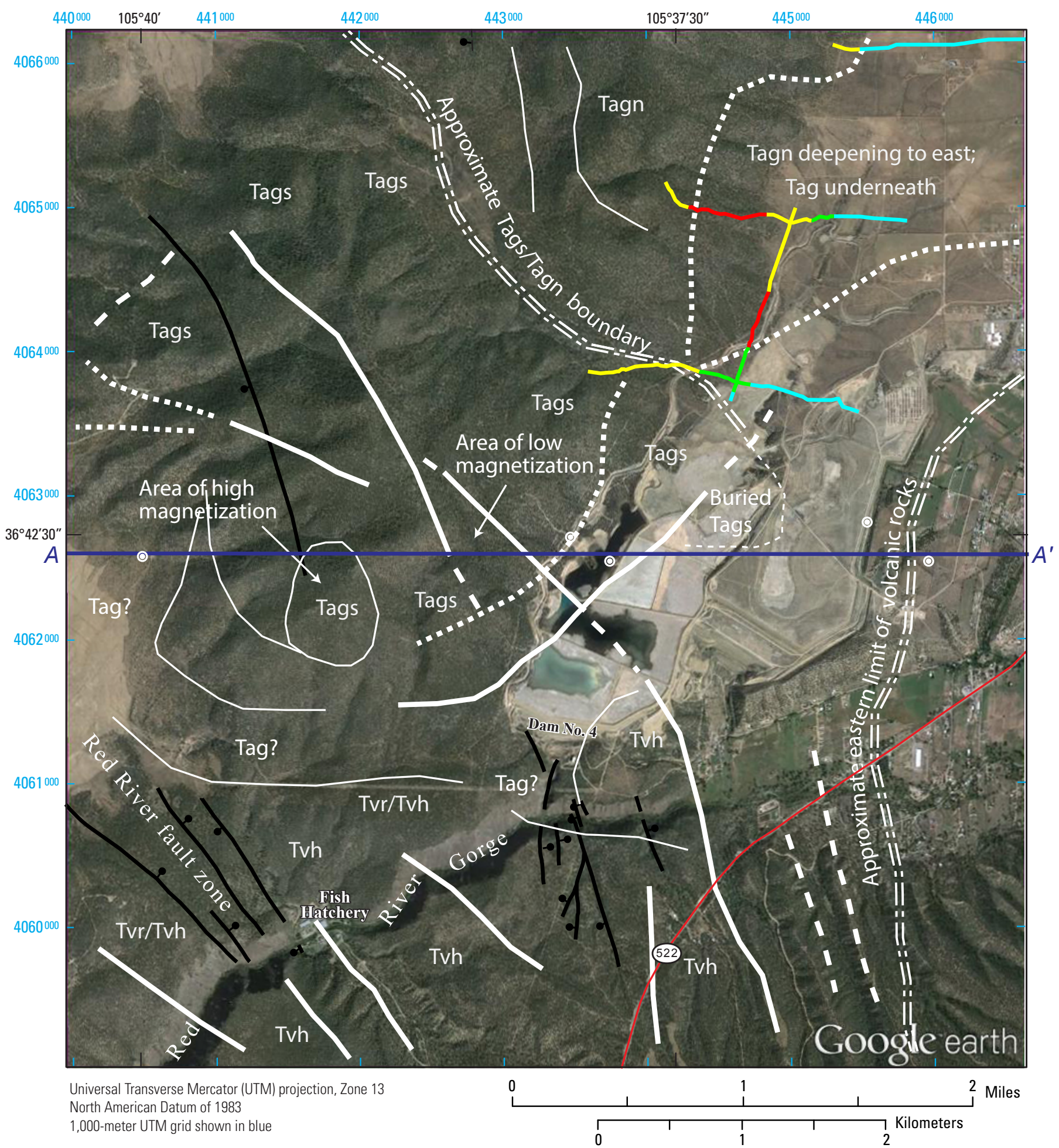

Figure 13. Interpretative lines and annotations of figure 7 overlain on the satellite image of the area from figure 1. 


\section{References Cited}

Appelt, R.M., 1998, ${ }^{40} \mathrm{Ar} /{ }^{39} \mathrm{Ar}$ Geochronology and volcanic evolution of the Taos Plateau volcanic field, northern New Mexico and southern Colorado: Socorro, N. Mex, New Mexico Institute of Mining and Technology, M.S. thesis, 58 p.

Bankey, Viki, Grauch, V.J.S., Webbers, Ank, and PRJ, Inc., 2005, Digital data and derivative products from a highresolution aeromagnetic survey of the central San Luis Basin, covering parts of Alamosa, Conejos, Costilla, and Rio Grande Counties, Colorado, and Taos County, New Mexico: U.S. Geological Survey Open-File Report 2005-1200. [Also available at http://pubs.usgs.gov/ of $/ 2005 / 1200 /$.

Bauer, P.W., and Kelson, K.I., 2004, Cenozoic structural development of the Taos area, New Mexico, in Brister, B.S., Bauer, P.W., Read, A.S., and Lueth, V.W., eds., Geology of the Taos region: New Mexico Geological Society, Guidebook, 55th Field Conference, p. 129-146.

Blakely, R.J., 1995, Potential theory in gravity and magnetic applications: United Kingdom, Cambridge University Press, $441 \mathrm{p}$.

Cordell, Lindrith, 1978, Regional geophysical setting of the Rio Grande rift: Geological Society of America Bulletin, v. 89, p. 1073-1090.

Cordell, Lindrith, and Grauch, V.J.S., 1985, Mapping basement magnetization zones from aeromagnetic data in the San Juan Basin, New Mexico, in Hinze, W.J., ed., The utility of regional gravity and magnetic anomaly maps: Tulsa, Okla., Society of Exploration Geophysicists, p. 181-197.

Cordell, Lindrith, and Keller, G.R., 1984, Regional structural trends inferred from gravity and aeromagnetic data in the New Mexico-Colorado border region, in Baldridge, W.S., Dickerson, P.W., Riecker, R.E., and Zidek, Jiri, eds., Rio Grande rift-Northern New Mexico: New Mexico Geological Society Guidebook, 35th Field Conference, p. 21-23.

Cosca, M.A., Thompson, R.A., Turner, K.J., and Lee, J.P., 2012, Pliocene volcanic evolution of the Taos Plateau, New Mexico: American Geophysical Union, 2012 Fall Meeting, San Francisco, Calif., Dec. 3-7, 2012, Abstract V33B-2853.

Cosca, M.A, Thompson, R.A, and Turner, K.J., 2014, High precision ${ }^{40} \mathrm{Ar} r{ }^{39} \mathrm{Ar}$ geochronology of Servilleta Basalts of the Rio Grande Gorge, New Mexico: American Geophysical Union, 2014 Fall Meeting, San Francisco, Calif., Dec. 15-19, 2014, Abstract V51A-4728.

Drenth, B.J., Grauch, V.J.S., and Rodriguez, B.D., 2013, Geophysical constraints on Rio Grande rift structure in the central San Luis Basin, Colorado and New Mexico, in Hudson, M.R., and Grauch, V.J.S., eds., New Perspectives on Rio Grande Rift Basins-From tectonics to groundwater: Geological Society of America Special Paper 494, p. 75-100. [Also available at http://dx.doi.org/10.1130/2013.2494(04).]
Dungan, M.A., Muehlberger, W.R., Leininger, L., Peterson, C., McMillan, N.J., Gunn, G., Lindstrom, M., and Haskin, L., 1984, Volcanic and sedimentary stratigraphy of the Rio Grande gorge and the Late Cenozoic geologic evolution of the southern San Luis Valley, in Baldridge, W.S., Dickerson, P.W., Riecker, R.E., and Zidek, Jiri, eds., Rio Grande riftNorthern New Mexico: New Mexico Geological Society Guidebook, 35th Field Conference, p. 157-170.

Grauch, V.J.S., 1987, A new variable-magnetization terrain correction method for aeromagnetic data: Geophysics, v. 52, no. 1, p. 94-107.

Grauch, V.J.S., and Cordell, L., 1987, Limitations of determining density or magnetic boundaries from the horizontal gradient of gravity or pseudogravity data: Geophysics, v. 52, no. 1, p. 118-121.

Grauch, V.J.S., and Connell, S.D., 2013, New perspectives on the geometry of the Albuquerque Basin, Rio Grande Rift, New Mexico-Insights from geophysical models of rift-fill thickness, in Hudson, M.R., and Grauch, V.J.S., eds., New Perspectives on Rio Grande Rift Basins-From tectonics to groundwater: Geological Society of America Special Paper 494, p. 427-462. [Also available at http://dx.doi.org/ doi:10.1130/2013.2494(16).]

Grauch, V. J. S., and Hudson, M. R., 2007, Guides to understanding the aeromagnetic expression of faults in sedimentary basins-Lessons learned from the central Rio Grande Rift, New Mexico: Geosphere, v. 3, no. 6, p. 596-623. [Also available at http://dx.doi.org/10.1130/10.1130/ GES00128.00121.]

Grauch, V.J.S., and Keller, G.R., 2004, Gravity and aeromagnetic expression of tectonic and volcanic elements of the southern San Luis Basin, New Mexico and Colorado, in Brister, B.S., Bauer, P.W., Read, A.S., and Lueth, V.W., eds., Geology of the Taos Region: New Mexico Geological Society Guidebook, 55th Field Conference, p. 230-243.

Heffern, E.L., 1990, A geologic overview of the Wild Rivers Recreation Area, New Mexico, in Bauer, P.W., Lucas, S.G., Mawer, C.K., and McIntosh, W.C., eds., Tectonic development of the southern Sangre de Cristo Mountains, New Mexico: New Mexico Geological Society, Guidebook, 41st Field Conference, p. 229-236.

Heywood, C.E., 1992, Isostatic residual gravity anomalies of New Mexico: U. S. Geological Survey, Water-Resources Investigations Report 91-4065, $27 \mathrm{p}$.

Hudson, M.R., and Grauch, V.J.S., 2013, Introduction, in Hudson, M.R., and Grauch, V.J.S., eds., New perspectives on Rio Grande Rift Basins-From tectonics to groundwater: Geological Society of America Special Paper 494, p. v-xi. [Also available at http://dx.doi.org/10.1130/2013.2494(00).] 
Ingersoll, R.V., Cavazza, W., Baldridge, W.S., and Shafiqullah, M., 1990, Cenozoic sedimentation and paleotectonics of northcentral New Mexico-Implications for initiation and evolution of the Rio Grande rift: Geological Society of America Bulletin, v. 102 , p. $1280-1296$.

Keller, G.R., and Baldridge, W.S., 1999, The Rio Grande rift-A geological and geophysical overview: Rocky Mountain Geology, v. 34, no. 1, p. 121-130.

Keller, G.R., Cordell, L., Davis, G.H., Peeples, W.J., and White, G., 1984, A geophysical study of the San Luis Basin, in Baldridge, W.S., Dickerson, P.W., Riecker, R.E., and Zidek, Jiri, eds., Rio Grande rift-Northern New Mexico: New Mexico Geological Society Guidebook, 35th Field Conference, p. 51-57.

Lipman, P.W., 1975, Evolution of the Platoro caldera complex and related volcanic rocks, southeastern San Juan Mountains, Colorado: U.S. Geological Survey Professional Paper 852, $128 \mathrm{p}$.

Lipman, P.W., 1983, The Miocene Questa caldera, northern New Mexico-Relation to batholith emplacement and associated molybdenum mineralization, in Babcock, J.W., The genesis of Rocky Mountain ore deposits - Changes with time and tectonics: Denver Region Exploration Symposium, Denver, Colo., 1982 [Proceedings], p. 133-149.

Lipman, P.W., and Mehnert, H.H., 1979, The Taos Plateau volcanic field, northern Rio Grande rift, New Mexico, in Riecker, R.E., ed., Rio Grande Rift-Tectonics and magmatism: Washington, D.C., American Geophysical Union, p. 289-311.

McElhinny, M.W., 1973, Paleomagnetism and plate tectonics: United Kingdom, Cambridge University Press, 358 p.

Ogg, J.G., and Smith, A.G., 2004, The geomagnetic polarity time scale, in Gradstein, F.M., Ogg, J.G., and Smith, A.G., eds., A geologic time scale: United Kingdom Cambridge University Press, p. 63-86.

Phillips, J.D., 1997, Potential-field geophysical software for the PC, version 2.2: U.S. Geological Survey Open-File Report 97-725, 39 p.
Read, A.S., Bauer, P.W., Thompson, R.A., Kelson, K.I., and Muehlberger, W.R., 2004, First-day road log from Taos to Questa, the Wild Rivers Recreation Area, Arroyo Hondo, the Dunn Bridge, the Rio Grande Gorge Bridge, and return to Taos, in Brister, B.S., Bauer, P.W., Read, A.S., and Lueth, V.W., eds., Geology of the Taos region: New Mexico Geological Society Guidebook, 55th Field Conference, p. 1-36.

Reynolds, R.L., Rosenbaum, J.G., Hudson, M.R., and Fishman, N.S., 1990, Rock magnetism, the distribution of magnetic minerals in the Earth's crust, and aeromagnetic anomalies, in Hanna, W.F., ed., Geologic applications of modern aeromagnetic surveys-Proceedings of the U.S. Geological Survey Workshop on Geological Applications of Modern Aeromagnetic Surveys, Lakewood, Colo., Jan. 6-8, 1987: U.S. Geological Survey Bulletin 1924, p. $24-45$.

Simpson, R.W., Jachens, R.C., Blakely, R.J., and Saltus, R.W., 1986, A new isostatic residual gravity map of the conterminous United States with a discussion on the significance of isostatic residual anomalies: Journal of Geophysical Research, v. 91, no. B8, p. 8348-8372.

Thompson, R.A., Cosca, M.A., Turner, K.A, Condit, C.B., Lee, J., Budahn, J.R., and Drenth, B.J., 2011, Pliocene volcanism of the Taos Plateau, Rio Grande Rift-New constraints on eruptive cycles, compositional trends and links to rift tectonism: American Geophysical Union, 2011 Fall Meeting, San Francisco, Calif., Dec. 5-9, 2011, Abstract V13C-2619.

Thompson, R.A., Johnson, C.M., and Mehnert, H.H., 1991, Oligocene basaltic volcanism of the northern Rio Grande Rift-San Luis Hills, Colorado: Journal of Geophysical Research, v. 96, no. B8, p. 13577-13592. [Also available at http://dx.doi.org/10.1029/91JB00068.]

Winograd, I.J., 1959, Ground-water conditions and geology of Sunshine Valley and western Taos County, New Mexico: New Mexico State Engineer Office, Technical Report No. 1.

Publishing support provided by:

Denver Publishing Service Center, Denver, Colorado

For more information concerning this publication, contact:

Director, USGS Crustal Geophysics and Geochemistry Science Center

Federal Center, Box 25046, MS 964

Denver, CO 80225

(303) 236-1373

Or visit the Crustal Geophysics and Geochemistry Science Center Web site at: http://crustal.usgs.gov/

This publication is available online at: http://dx.doi.org/10.3133/ofr20151129 



\section{$\frac{\mathbb{3}}{3}$}

